\title{
Hydrography and Circulation of the Bay of Bengal during withdrawal phase of the southwest Monsoon
}

\author{
Y.V.B. SARMA, E.P. RAMA RAO, P.K. SAJI, V.V.S.S. SARMA \\ National Institute of Oceanography, Dona Paula, Goa 403 004, India
}

(Received 4 June 1998, revised 23 March 1999, accepted 6 May 1999)

\begin{abstract}
Hydrographic data were collected from 3 to 10 September 1996 along two transects; one at $18^{\circ} \mathrm{N}$ and the other at $90^{\circ} \mathrm{E}$. The data were used to examine the thermohaline, circulation and chemical properties of the Bay of Bengal during the withdrawal phase of the southwest monsoon. The surface salinity exhibited wide spatial variability with values as low as 25.78 at $18^{\circ} \mathrm{N} / 87^{\circ} \mathrm{E}$ and as high as 34.79 at $8^{\circ} \mathrm{N} / 90^{\circ} \mathrm{E}$. Two high salinity cells ( $\mathrm{S}>35.2$ ) were noticed around 100 $\mathrm{m}$ depth along the $90^{\circ} \mathrm{E}$ transect. The wide scatter in T-S values between 100 and $200 \mathrm{~m}$ depth was attributed to the presence of the Arabian Sea High Salinity (ASHS) water mass. Though the warm and low salinity conditions at the sea surface were conducive to a rise in the sea surface topography at $18^{\circ} \mathrm{N} / 87^{\circ} \mathrm{E}$, the dynamic height showed a reduction of 0.2 dyn.m. This fall was attributed to thermocline upwelling at this location. The geostrophic currents showed alternating flows across both the transects. Relatively stronger and mulually opposite currents were noticed around 25 in depth across the $18^{\circ} \mathrm{N}$ transect with velocity slightly in excess of $30 \mathrm{~cm} \mathrm{~s}^{-1}$. Similar high velocity $\left(>40 \mathrm{~cm} \mathrm{~s}^{-1}\right)$ pockets were also noticed to extend up to $30 \mathrm{~m}$ depths in the southern region of the $90^{\circ} \mathrm{E}$ transect. However, the currents below $250 \mathrm{~m}$ were weak and in general $<5 \mathrm{~cm} \mathrm{~s}^{-1}$. The net geostrophic volume transports were found to be of the order of $1.5 \times 10^{6} \mathrm{~m}^{3} \mathrm{~s}^{-1}$ towards the north and of $6 \times 10^{6} \mathrm{~m}^{3} \mathrm{~s}^{-1}$ towards west across the $18^{\circ} \mathrm{N}$ and $90^{\circ} \mathrm{E}$ transects respectively. The surface circulation patterns were also investigated using the trajectories of drifting buoys deployed in the eastern Indian Ocean around the same observation period. Poleward movement of the drifting buoy with the arrival of the Indian Monsoon Current (IMC) at about $12^{\circ} \mathrm{N}$ along the eastern rim of the Bay of Bengal has been noticed to occur around the beginning of October. The presence of an eddy off the southeast coast of India and the IMC along the southern periphery of the Bay of Bengal were also evident in the drifting buoy data. (C) 1999 Ifremer / CNRS / IRD / Éditions scientifiques et médicales Elsevier SAS
\end{abstract}

\section{hydrography / watermass / circulation / Monsoon / Bay of Bengal}

Résumé - Hydrologie et circulation dans le golfe du Bengale à la renverse de la mousson du sud-ouest. La circulation thermohaline et les propriétés chimiques du golfe du Bengale sont étudiées pendant la phase de renversement de la mousson du sud-ouest; les données hydrologiques ont été collectées du 3 au 10 septembre 1996 sur deux radiales, l'une à $18^{\circ} \mathrm{N}$, l'autre suivant $90^{\circ} \mathrm{E}$. La salinité de surface présente une grande variabilité spatiale, de $25,78\left(\operatorname{par} 18^{\circ} \mathrm{N} / 87^{\circ} \mathrm{E}\right.$ ) jusqu'à 34,79 (par $8^{\circ} \mathrm{N} / 90^{\circ} \mathrm{E}$ ), avec deux maxima (plus de 35,2) vers $100 \mathrm{~m}$ de profondeur sur la radiale $90^{\circ} \mathrm{E}$. La forte dispersion des températures et des salinités, observée entre 100 et $200 \mathrm{~m}$ de profondeur, est attribuée à l'eau très salée en provenance de la mer d'Arabie (ASHS). Bien que les eaux superficielles chaudes et peu salées élèvent la topographie de la surface par $18^{\circ} \mathrm{N} / 87^{\circ} \mathrm{E}$, la hauteur dynamique présente une baisse de $0.2 \mathrm{~m}$ dyn, attribuée ici à la remontée de la thermocline. Les flux géostrophiques sont alternés à travers les deux radiales. Des courants relativement plus forts (dépassant $30 \mathrm{~cm} \mathrm{~s}^{-1}$ ) et opposés sont observés vers $25 \mathrm{~m}$ de profondeur à travers la radiale $18^{\circ} \mathrm{N}$. Des poches similaires de fort courant (plus de $40 \mathrm{~cm} \mathrm{~s}^{-1}$ ) dépassent $30 \mathrm{~m}$ de profondeur dans la partie sud de la radiale $90^{\circ} \mathrm{E}$. Cependant, au-dessous de $250 \mathrm{~m}$ de profondeur, les courants sont faibles (moins de $5 \mathrm{~cm} \mathrm{~s}^{-1}$ ). Les flux géostrophiques nets sont respectivement de l'ordre de $1,5 \times 10^{6} \mathrm{~m}^{3} \mathrm{~s}^{-1}$ vers le nord et $6 \times 10^{6} \mathrm{~m}^{3} \mathrm{~s}^{-1}$ vers l'ouest à travers les radiales $18^{\circ} \mathrm{N}$ et $90^{\circ} \mathrm{E}$. Les schémas de la 
circulation superficielle sont établis à partir des trajectoires de bouées dérivantes déployées dans l'est de l'océan Indien pendant la même période. Le mouvement est dirigé vers le pôle au début du mois d'octobre, à l'arrivée du Courant Indien de Mousson (IMC) le long du bord oriental du golfe du Bengale, vers $12^{\circ} \mathrm{N}$. La dérive des bouées met en évidence la présence d'un tourbillon au large de la côte sud-est de l'Inde et le Courant Indien de Mousson à la périphérie du golfe du Bengale. (C) 1999 Ifremer / CNRS / IRD / Éditions scientifiques et médicales Elsevier SAS

\section{hydrologie / masse d'eau / circulation / mousson / golfe du Bengale}

\section{INTRODUCTION}

The northern Indian Ocean as a whole is characterized by the reversing monsoons; summer monsoon (also known locally as southwest monsoon) during June, July, August and September and winter monsoon (known as northeast monsoon) during November, December, January and February [26]. The Bay of Bengal forms the northeastern part of the Indian Ocean and is characterized by complex current systems that vary in strength and location both

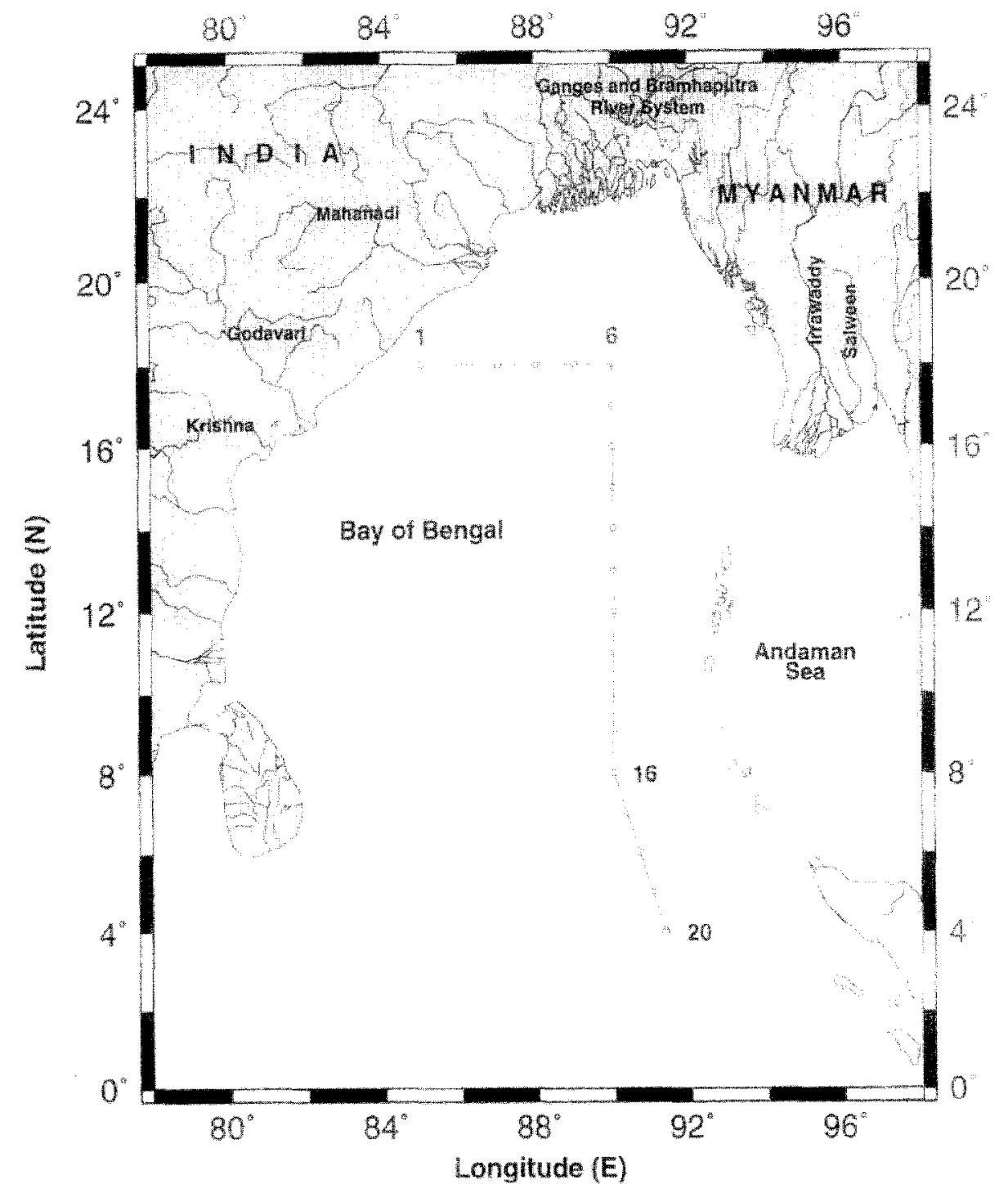

Figure 1. Area of study along with CTD locations (prepared using GMT software). 
seasonally and inter-annually $[5,8,13,21,25,28]$. It is a scmi-cnclosed water body cxtending from $6^{\circ} \mathrm{N}$ to $24^{\circ} \mathrm{N}$ and from $80^{\circ} \mathrm{E}$ to $92^{\circ} \mathrm{E}$. The continental shelf along the east coast of India is very narrow in the south and gradually widens towards north with an average width of about $40 \mathrm{~km}$. The coastline itself has interesting geomorphological features such as a northeast-oriented coastline from the southern end of the peninsula to $10^{\circ} \mathrm{N}$ which abruptly, turns to east-west and then orients in rather a north-south direction from $10^{\circ} \mathrm{N}$ to $13.5^{\circ} \mathrm{N}$. Beyond it, rather abruptly, the coastline orientation changes to southwest-northeast direction. This feature presumably plays a critical role in the circulation along the east coast of India as was evident from the selective upwelling zones, northward coastal current and variable offshore Ekman transport along the northwestern Bay during the southwest monsoon period [23]. The summer monsoon is the single largest event that brings about large scale changes in circulation $[3,16,17,19,24]$ and heat content distribution of the Bay of Bengal [18]. The flow pattern becomcs disorganised and breaks into a multitude of mesoscale gyres in the Bay of Bengal during the southwest monsoon season $[4,7,12]$. During this season the Bay of Bengal receives excessive precipitation and freshwater runoff from several major and minor rivers all along the east coast of India. The effect of these factors on the distribution of physical and chemical properties and the circulation of the Bay is expected to be reflected by September when the withdrawal of the southwest monsoon system begins from this region. The hydrographic observations along $90^{\circ} \mathrm{E}$ were planned to complement the WOCE hydrographic data along section I-5 in the eastern Indian Ocean further north.

The weather conditions during the cruise period were characterized by easterlies of about $5 \mathrm{~m} \mathrm{~s}^{-1}$ north of $13^{\circ} \mathrm{N}$ and strong southwesterlies of about $10 \mathrm{~m} \mathrm{~s}^{-1}$ with speeds occasionally exceeding $15 \mathrm{~m} \mathrm{~s}^{-1}$ in the south (figure 2) which is the characteristic feature of the southwest

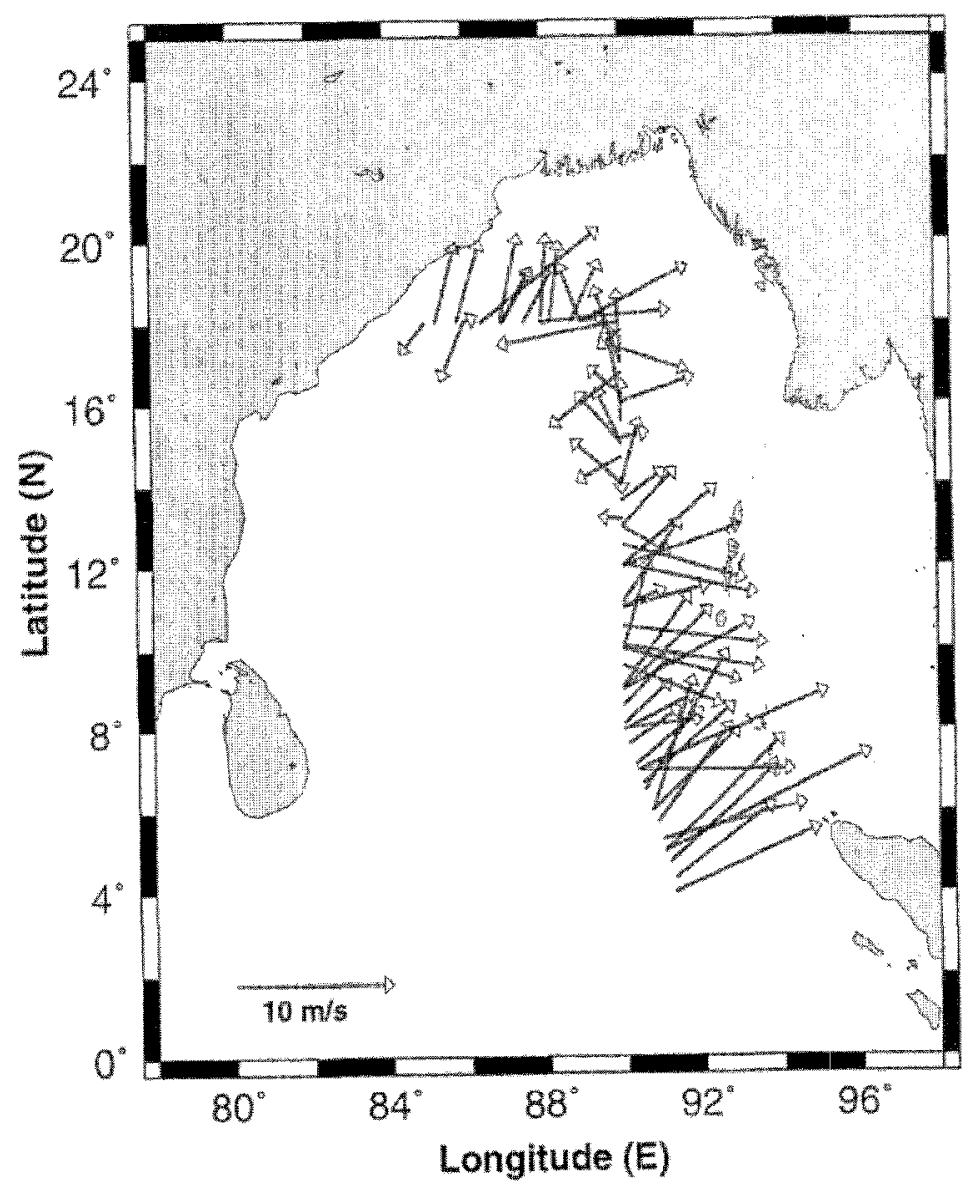

Figure 2. Distribution of wind $\left(\mathrm{m} \mathrm{s}^{-1}\right)$ vector along the cruise track. 
monsoon trough. In general, weather was clear in the northern Bay but cloudy towards south of $13^{\circ} \mathrm{N}$. The rainfall recorded around $11^{\circ} \mathrm{N} / 90^{\circ}$ E over the sea region on September 7 was as high as $57 \mathrm{~mm}$. The wind patterns indicate the beginning of southwest monsoon withdrawal from the northern Bay of Rengal.

In this article, we present an analysis of the results of hydrographic observations and discuss the water masses and circulation patterns along with associated volume transport structure in the Bay during the withdrawal phase of the southwest monsoon.

\section{DATA AND METHODS}

The hydrographic data using CTD were collected on board ORV Sagar Kanya from 3 to 10 September, 1996. Altogether 20 CTD stations were occupied along a zonal $\left(18^{\circ} \mathrm{N}\right)$ and a meridional $\left(90^{\circ} \mathrm{E}\right)$ transect as shown in figure 1. The CTD probe used (Sea Bird Electronics, Inc., USA, model: SBE-11 plus) has the following resolution and accuracy limits: pressure: $0.001 \%$ and $0.15 \%$ of full scale, temperature: $0.0002{ }^{\circ} \mathrm{C}$ and $0.002^{\circ} \mathrm{C}$ and salinity: 0.0004 and 0.003 . Water samples were also collected with $15 \mathrm{~L}$ Niskin samplers mounted on the CTD rosette and analysed using a calibrated salinometer (Guildline, Autosal model: $8400 \mathrm{~A}$ ). The salinity values obtained both by CTD and the Autosal were regressed to verify the drift in the CTD salinity measurements. We found that both CTD and the Autosal salinity values correlated excellently $(r=0.998)$ with a constant salinity difference $(0.03)$ between these values with the CTD salinity values marginally on the lower side. The geostrophic currents and the volume transport estimates were computed relative to $1000 \mathrm{~m}$ depth. The heat content was computed with respect to a $13{ }^{\circ} \mathrm{C}$ isotherm which is considered as the base of the thermocline. In this process the heat content changes due to vertical motions caused by divergence (or convergence) occurring in the water column above the base of the thermocline were properly accounted for while examining the upper ocean heat budget [9].

Water samples were analysed for the total Carbon dioxide $\left(\mathrm{TCO}_{2}\right)$, total alkalinity and $\mathrm{pH}$. $\mathrm{TCO}_{2}$ was measured using a coulometer following the procedure detailed in George et al. [10] but with a semi-automated sample drawing system. Total alkalinity and $\mathrm{pH}$ were analysed using a high precision spectrophotometric method (at (a)

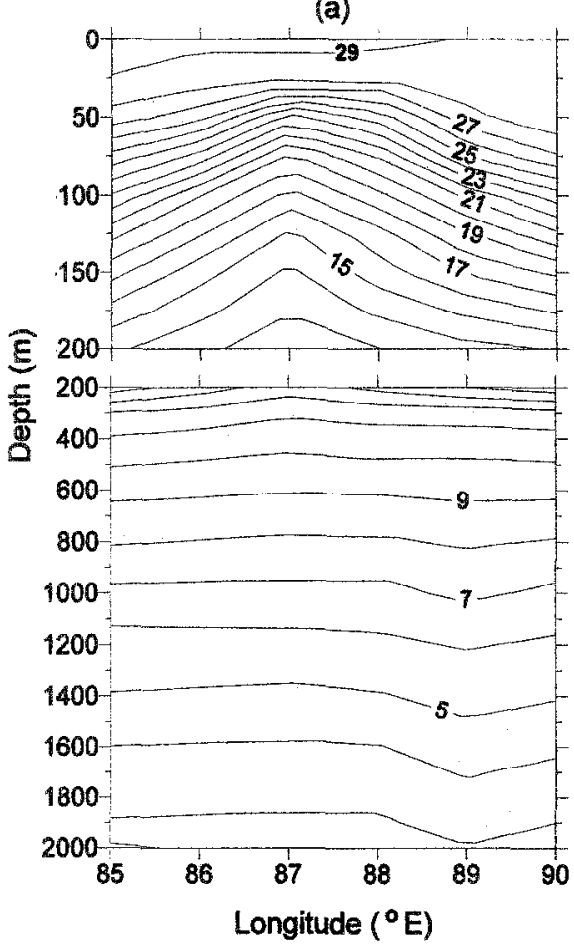

(b)

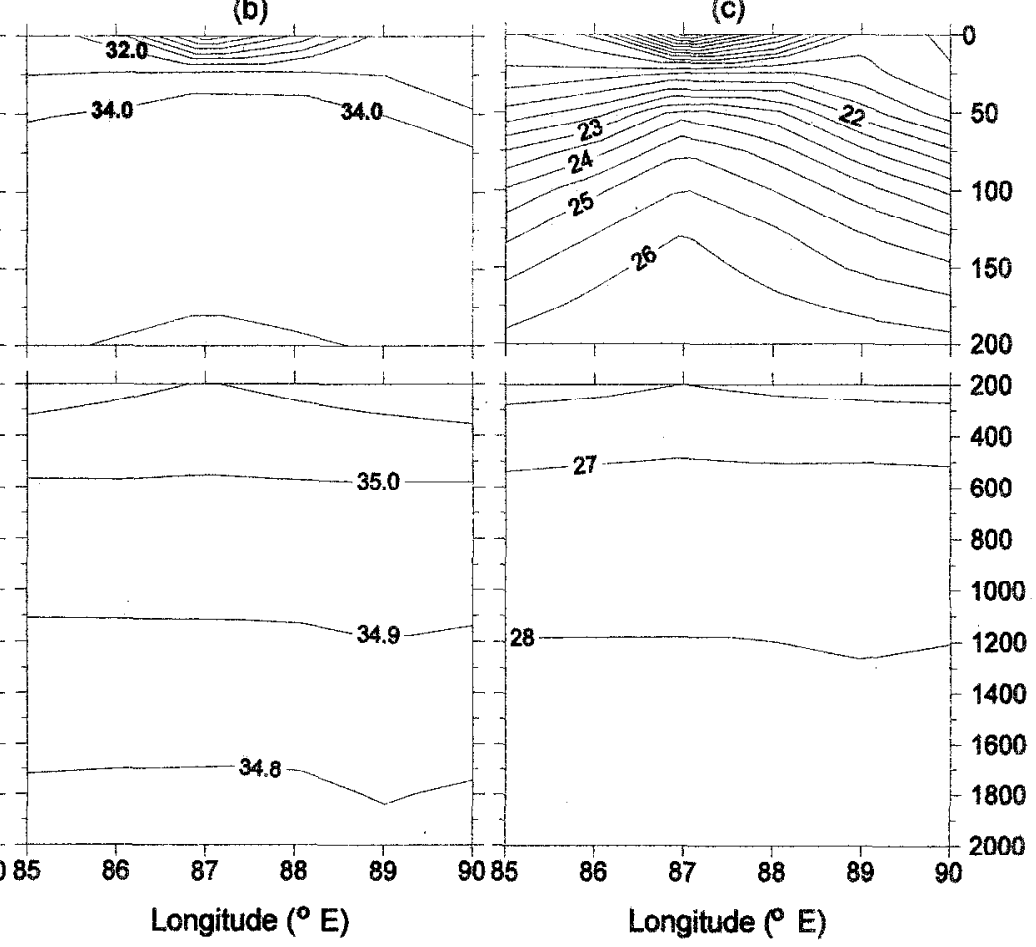

Figure 3. Vertical structure of (a) temperature $\left({ }^{\circ} \mathrm{C}\right)$, (b) salinity and $(\mathrm{c}) \sigma_{\theta}\left(\mathrm{kg} \mathrm{m}^{-3}\right)$ along $18^{\circ} \mathrm{N}$ transect. 
$25^{\circ} \mathrm{C}$ ) using the indicators Bromocresol Green and Cresol Red, respectively. The analytical precisions for $\mathrm{TCO}_{2}$ and $\mathrm{pH}$ are $\pm 2.0 \mu \mathrm{M}$ and \pm 0.002 respectively, while that for the calculated parameter, $\mathrm{pCO}_{2}$ is $\pm 4.0 \mu \mathrm{atm}$.

In addition, the data from the Metocean drifting buoys deployed in the Indian Ocean region as part of an ongoing project on "Sea Truth Data Collection" (sponsored by the Department of Ocean Development, New Delhi) were used to examine the surface circulation in conjunction with hydrographic data. The data Collection and Location System (CLS) installed onboard NOAA satellites receives the buoy positions that are transmitted via ARGOS transmitters. They were then routed through the NOAA/NESDIS data processing and service subsystem to an ARGOS global processing centre in Toulouse, France. Finally, these data sets were received on magnetic tapes and processed at the National Institute of Oceanog- raphy, India. On the Metocean WOCE-type buoy the digital controller samples each sensor (except submergence) once every $90 \mathrm{~s}$. Submergence is measured four times every $90 \mathrm{~s}$. Every $20 \mathrm{~min}$ the data acquired for the past $20 \mathrm{~min}$ are averaged and a new message is generated for transmission. If a barometer sensor is present, 160 samples are taken by this sensor during the $20 \mathrm{~min}$ period and averaged. The buoy location is achieved by measuring the "Doppler shift" on the platform signals. The dual position ambiguity is removed using additional information, such as previous location and range of possible speeds. Prior to position calculation geometric tests are carried out to eliminate excessive erroneous frequency shift and unacceptable distance from ground track. Along with the data stream, Service ARGOS provides a location class to indicate the accuracy of each location. The classes are 3,2,1 and 0 corresponding to an accuracy better than $150 \mathrm{~m}$, $350 \mathrm{~m}, 100 \mathrm{~m}$ and quality to be determined by user. Each record was checked against the 'checksums' provided in
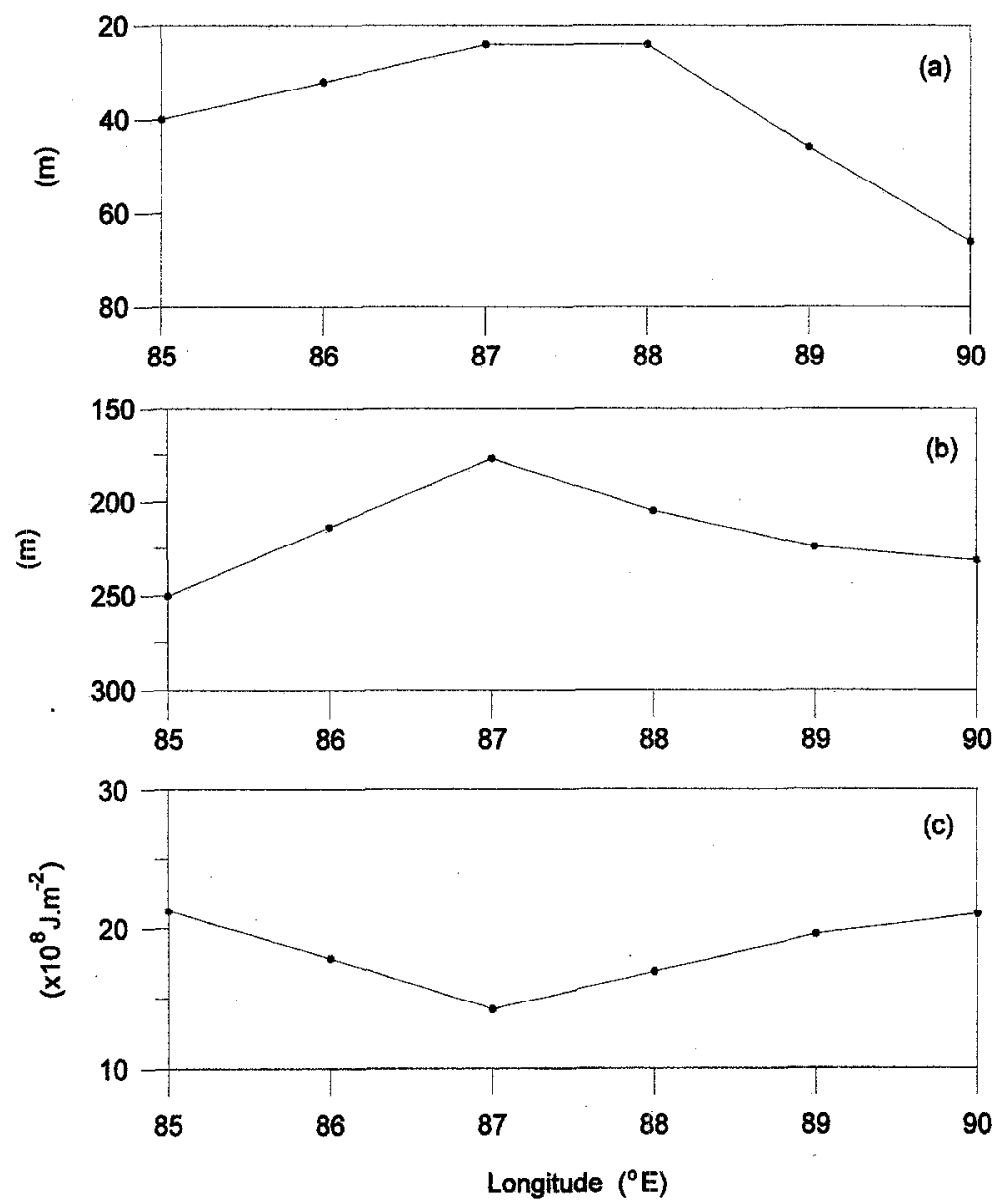

Figure 4. Distribution of (a) mixed layer thickness (m), (b) thermocline depth (m) and (c) heat content $\left(\times 10^{8} \mathrm{~J} \mathrm{~m}^{-2}\right)$ along $18^{\circ} \mathrm{N}$ transect. 
the data stream. Only the records which matched the checksums were accepted. Location classes are deter. mined by least square fits and another probabilistic means procedure suggested by Hanson and Poulain [11] based on speed checks between consecutive locations. Details of this editing scheme can be found in Hanson and Poulain [11]. All calculations to find the distance between tow positions and the azimuth are done on a spheroid following the methods described in Admiralty Manual of Hydrographic Surveying (1965). A maximum value above which velocities are considered bad is determined based on our knowledge of the circulation in the area where the buoy moved and on the surface currents climatology of Cutler and Swallow [7]. Unreliable velocity observation corresponds to a pair, rather than a single point, one has to decide which point of the pair is the unreliable location. Due to the diversity of time intervals between sequential positions, the decision on which point of the pair is the flawed location is not trivial. Hence to identify the flawed location a simple forward and backward search in time is adopted. The peaks in raw data related to buoy positional ambiguity were removed using additional information such as previous location and range of climatologically possible speeds for a given region [22].

\section{RESULTS}

\section{1. $18^{\circ} \mathrm{N}$ transect}

It was observed that in the Bay of Bengal the changes in hydrographic properties are rather rapid in the upper $200 \mathrm{~m}$. Hence the distribution maps of temperature, salinity and potential density $\left(\sigma_{\theta}\right)$ were plotted on two different vertical scales as $0-200 \mathrm{~m}$ and $200-2000 \mathrm{~m}$. The sea surface temperature (SST) varied between $28.9^{\circ} \mathrm{C}$ and $29.6^{\circ} \mathrm{C}$ along this transect (figure $3 a$ ). The freshwater appeared as a thin surface low salinity plume $(<10 \mathrm{~m}$ thickness). Salinity was the most dramatically varying parameter along this transect, hence the vertical structure of salinity in the upper $200 \mathrm{~m}$ was contoured at an interval of one salinity unit. Salinity rapidly increased from 25.78 at surface to 34.29 at $30 \mathrm{~m}$ depth at $87^{\circ} \mathrm{E}$ (figure $3 b$ ). Below this depth the ambient salinity was higher than that at the surrounding locations. The surface water density, $\sigma_{\theta}$, decreased to $14.9 \mathrm{~kg} \mathrm{~m}^{-3}$ at $87^{\circ} \mathrm{E}$ due to the freshwater plume at this location (figure $3 \mathrm{c}$ ). The surface density distribution was governed by salinity, as can be seen from a higher surface density $\left(>20 \mathrm{~kg} \mathrm{~m}^{-3}\right)$ resulting from an increase in surface salinity at $89^{\circ} \mathrm{E}$.
However, below $100 \mathrm{~m}$ depth, where salinity variation was only marginal, the density was controlled by temperature as was evident from the presence of denser waters, $\sigma_{\theta}>26.2 \mathrm{~kg} \mathrm{~m}^{-3}$, around $150 \mathrm{~m}$ depth at $87^{\circ} \mathrm{E}$ where a thermocline upwelling was noticed. Thus salinity governed the distribution of density in the surface layers while temperature controlled the density of subsurface waters along this transect. The thickness of the surface mixed layer, taken as the depth where the ambient temperature is $1{ }^{\circ} \mathrm{C}$ less than the SST, was small $(28 \mathrm{~m})$ where low salinity plume was observed (figure $4 a$ ). It increased to $60 \mathrm{~m}$ at $90^{\circ} \mathrm{E}$ where warm saline waters were present. The distribution of the thermocline depth, taken as the depth of the $13{ }^{\circ} \mathrm{C}$ isotherm [6], showed a thermocline upwelling at $87^{\circ} \mathrm{E}$ with strong vertical stratification and halocline generated by river runoff at the surface. This appears to have prevented a turbulent mixing which could have led to the development of a deep mixed layer at this location. The thermocline was found to be tilted towards the coast as it deepened from $175 \mathrm{~m}$

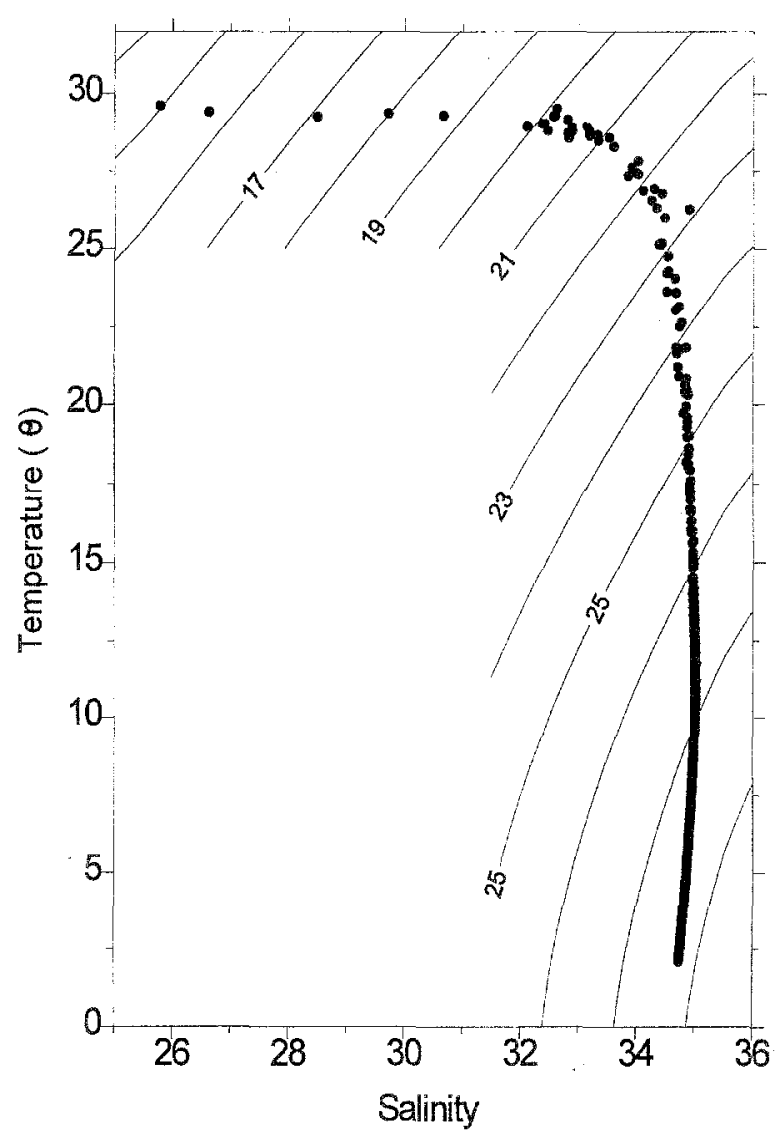

Figure 5. $\theta-\mathrm{S}$ scatter along $18^{\circ} \mathrm{N}$ transect. 
at $87^{\circ} \mathrm{E}$ to about $250 \mathrm{~m}$ depth towards either end of this transect (figure $4 b$ ). The heat content of the upper ocean was computed with respect to the $13{ }^{\circ} \mathrm{C}$ isotherm and its distribution along $18^{\circ} \mathrm{N}$ transect is shown in figure $4 \mathrm{c}$. The vertical movement of the thermocline appears to have a direct influence on the heat content changes in the upper ocean. It was found to be lower $\left(14 \times 10^{8} \mathrm{~J} \mathrm{~m}^{-2}\right)$ at $87^{\circ} \mathrm{E}$ and rapidly increased to about $21 \times 10^{8} \mathrm{~J} \mathrm{~m}^{-2}$ towards either side of the transect. While sinking of the thermocline increased the heat content near $85^{\circ} \mathrm{E}$, the deepening of the mixed layer appears to be responsible for higher values of heat content at $90^{\circ} \mathrm{E}$.

The water mass structure as depicted in the temperaturesalinity scatter diagram (figure 5), showed a wide scatter at the surface which was obviously due to the freshwater plume present at $87^{\circ} \mathrm{E}$. Since this transect lies in the northern region of the Bay, it depicted the typical changes in the temperature and salinity that accompany freshwater influx, a predominant event that occurs at this time of the year following the southwest monsoon season. The region between 22.5 and $24.5 \sigma_{\theta}$ surfaces shows high salinity water masses.

The geostrophic currents across the $18^{\circ} \mathrm{N}$ transect showed strong southward flow between $85^{\circ}$ and $87^{\circ} \mathrm{E}$ and northward flow across the rest of the transect (figure 6). The currents were found to be stronger at the subsurface, around $20 \mathrm{~m}$ depth $\left(>30 \mathrm{~cm} \mathrm{~s}^{-1}\right)$, than at the surface (about $20 \mathrm{~cm} \mathrm{~s}^{-1}$ ) in both cases. The southerly currents west of $87^{\circ} \mathrm{E}$ were driving the low salinity plume from the northern Bay while the northerly currents east of $87^{\circ} \mathrm{E}$ were bringing in the warm high salinity waters noticed around $90^{\circ} \mathrm{E}$ from the south.

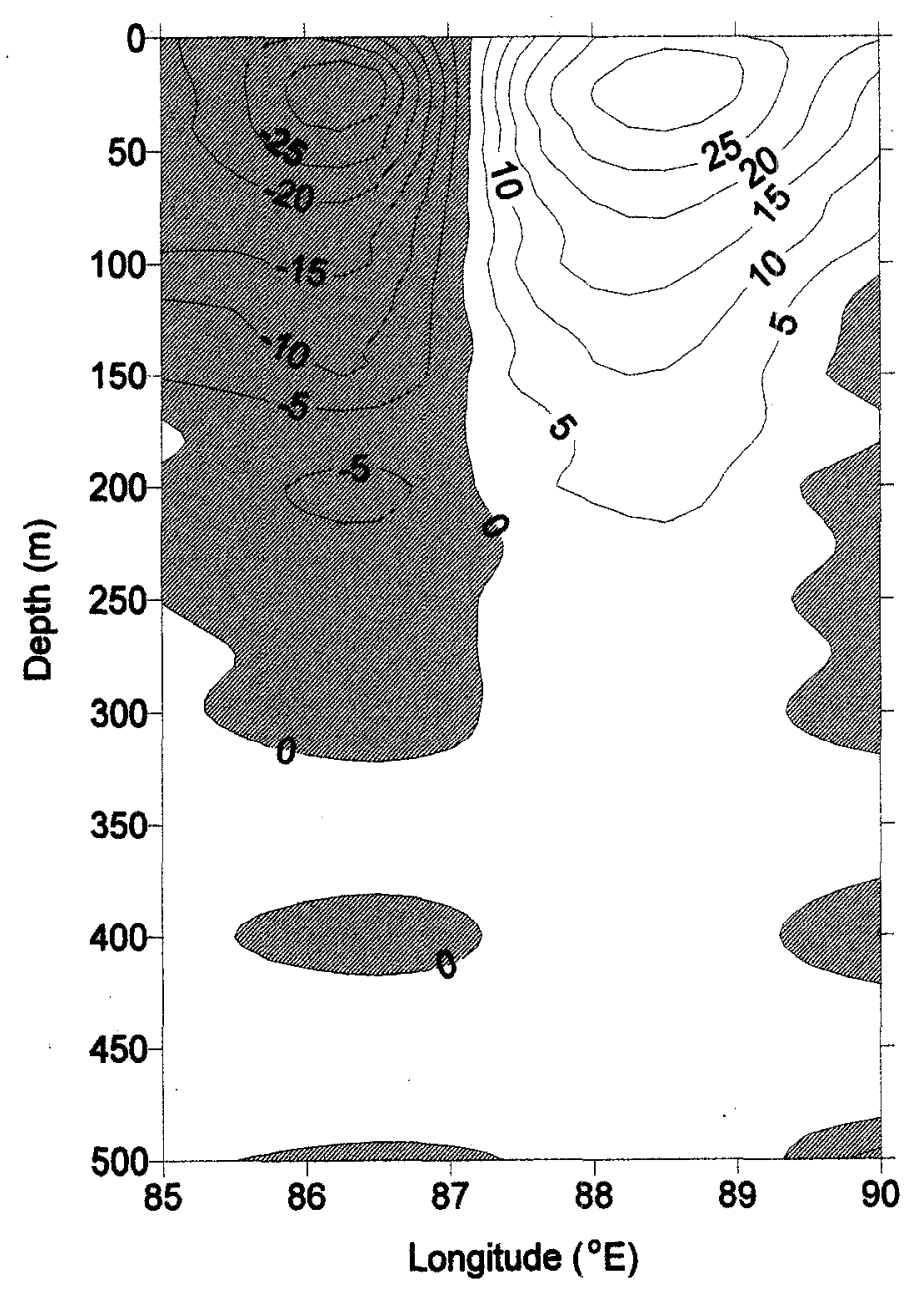

Figure 6. Vertical structure of geostrophic currents $\left(\mathrm{cm} \mathrm{s}^{-1}\right)$ across the $18^{\circ} \mathrm{N}$ transect (North $\square$, South 


\section{2. $90^{\circ} \mathrm{E}$ transect}

The distributions of temperature, salinity and $\sigma_{\theta}$ in the upper $1000 \mathrm{~m}$ between $18^{\circ}$ and $4^{\circ} \mathrm{N}$ are presented in $f i g$ ures $7 a$ and $c$. The SST varied between $28.1^{\circ} \mathrm{C}$ and $29.0^{\circ} \mathrm{C}$ along this transect with lower SST at $8^{\circ} \mathrm{N}$ and higher SST at $15^{\circ} \mathrm{N}$ (figure 7a). The surface salinity along this transect varied between 31.04 and 34.79 with low salinity occurring at $14^{\circ} \mathrm{N}$ and high salinity at $8^{\circ} \mathrm{N}$. The vertical structure of salinity showed two prominent cells of high salinity spreading between 70 and $130 \mathrm{~m}$ depth at $8^{\circ} \mathrm{N}$ and $12^{\circ} \mathrm{N}$ with their core salinity values $\mathrm{S}>35.7$ and $\mathrm{S}>35.2$ respectively (figure $7 b$ ). The vertical dimension of the northern cell was smaller $(25 \mathrm{~m})$ than the southern cell $(55 \mathrm{~m})$ with the horizontal dimension nearly the same for both these cells $(\approx 200 \mathrm{~km})$. These cells were spatially separated by about $300 \mathrm{~km}$. Apart from these high salinity cells, the subsurface salinity, in general gradually increased towards the south along this transect. The surface density varied between 19.09 and $22.19 \mathrm{~kg} \mathrm{~m}^{-3}$ with the lower value coinciding with a low salinity tongue at $14^{\circ} \mathrm{N}$ and the higher value with high salinity waters at $8^{\circ} \mathrm{N}$ (figure $7 \mathrm{c}$ ). In the subsurface layers, the salinity and temperature contributed constructively to the increase in density.

(a)

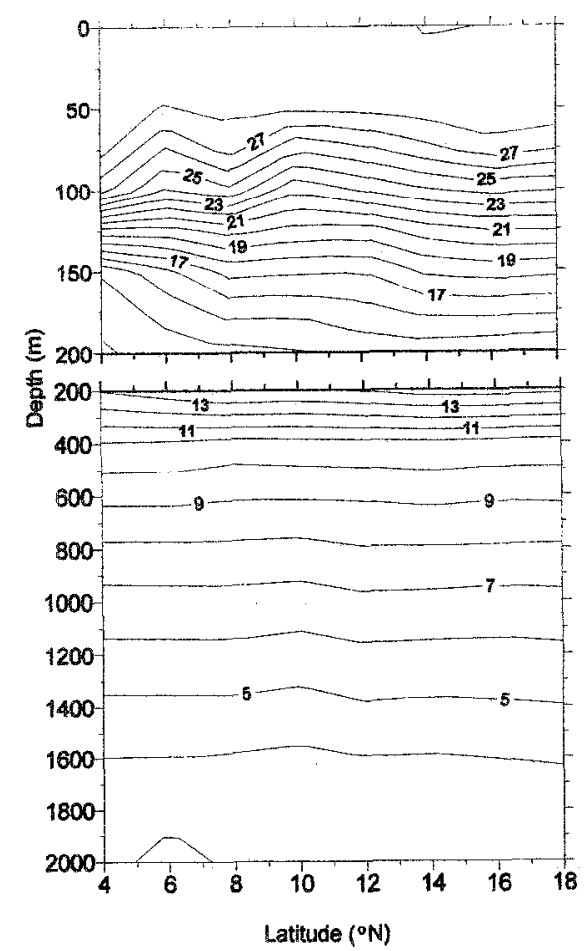

(b)

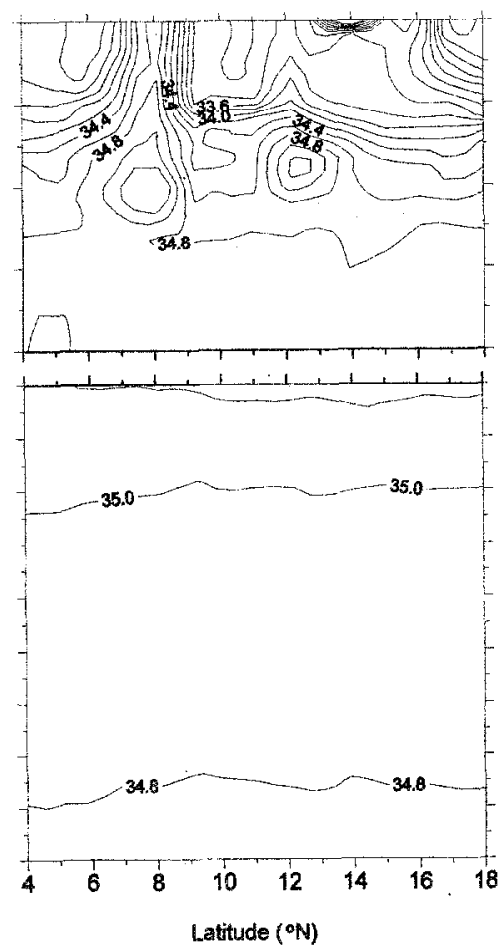

The distributions of mixed layer thickness, thermocline thickness and the heat content along this transect are presented in figures $8 a$ and $c$. The surface mixed layer varied between 52 and $92 \mathrm{~m}$ (figure 8a). Large oscillation in the mixed layer thickness was noticed at the southern part of this transect between $4^{\circ}$ and $9^{\circ} \mathrm{N}$. The deepening of the mixed layer at $16^{\circ} \mathrm{N}$ was found to be associated with a decrease in the SST while increase in SST was found to result in the reduction in the mixed layer thickness at $9^{\circ} \mathrm{N}$. The distribution of the thermocline thickness is presented in figure $8 b$. The vertical movement of the thermocline was only about $\pm 25 \mathrm{~m}$ from its mean position along this transect. This does not appear to have influenced the heat content changes in the upper ocean (figure 8c). The higher heat content $\left(22.6 \times 10^{8} \mathrm{~J} \mathrm{~m}^{-2}\right)$ is associated with warm low saline waters from the Andman Sea around $14^{\circ} \mathrm{N}$ while the lower heat content $\left(18 \times 10^{8} \mathrm{~J} \mathrm{~m}^{-2}\right)$ was observed at $4^{\circ} \mathrm{N}$ along this transect. The changes in the mixed layer thickness rather than in the thermocline depth appear to control the upper ocean heat content along $90^{\circ} \mathrm{E}$.

The temperature-salinity scatter along this transect has also shown significant variability in the surface salinity while the temperature changes were only marginal b) (c)

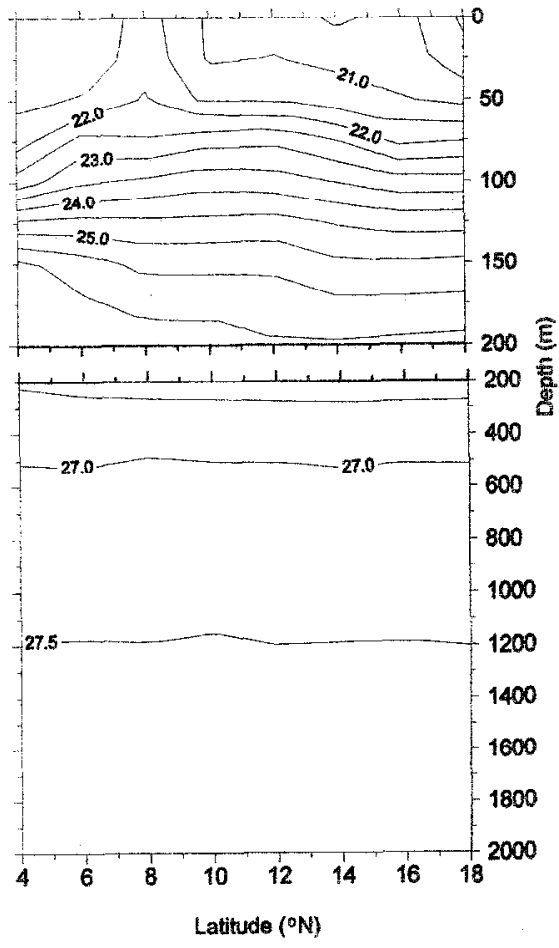

Figure 7. Vertical Structure of (a) temperature $\left({ }^{\circ} \mathrm{C}\right)$, (b) salinity and (c) $\sigma_{\theta}\left(\mathrm{kg} \mathrm{m}^{-3}\right)$ along the $90^{\circ} \mathrm{E}$ transect. 
(figure 9). A low salinity surface water mass and the subsurface high salinity water masses observed along this transect were conspicuously noticed on this T-S scatter diagram. The low salinity water mass was noticed at $<19$ $\sigma_{\theta}$ surface, while the high salinity water masses were present between 23.0 and $24.0 \sigma_{\theta}$ surfaces corresponding to the Arabian Sea High Salinity (ASHS) water mass.

Westward geostrophic currents dominated a large part of the transect between $8^{\circ}$ and $15^{\circ} \mathrm{N}$ (figure 10). A strong wavy pattern as depicted by alternating flows was observed along this transect between $4^{\circ}$ and $9^{\circ} \mathrm{N}$. Such regularly spaced oscillations in the flow direction could possibly be the manifestation of westward-propagating low frequency waves [12] or mesoscale gyres generated by the advent of the IMC in this region. A narrow and shallow stream of easterly current was noticed between $5^{\circ}$ and $6^{\circ} \mathrm{N}$ with a core velocity of about $45 \mathrm{~cm} \mathrm{~s}^{-1}$ around $30 \mathrm{~m}$ depth. The current velocities were $<5 \mathrm{~cm} \mathrm{~s}^{-1}$ over most of the region allong this transect.

\section{DISCTISSION}

The surface salinity exhibited wide variations with values reducing to as low as 25.78 at $18^{\circ} \mathrm{N} / 87^{\circ} \mathrm{E}$ and gradu-
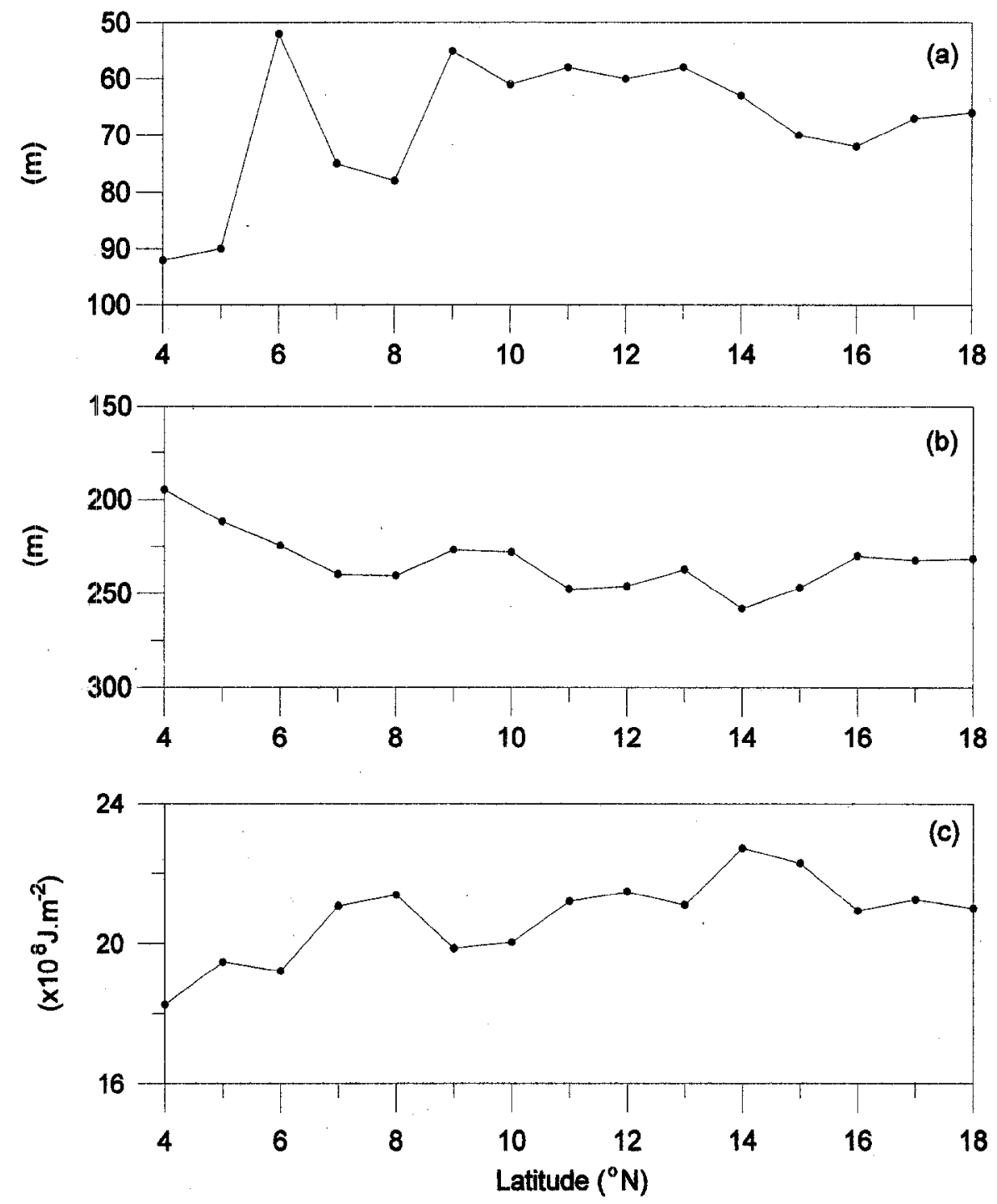

Figure 8. Distribution of (a) mixed layer thickness (m), (b) thermocline depth (m) and (c) heat content $\left(\times 10^{8} \mathrm{~J} \mathrm{~m}{ }^{-2}\right)$ along $90^{\circ} \mathrm{E}$ transect. 
ally increasing to 34.79 at $8^{\circ} \mathrm{N} / 90^{\circ} \mathrm{E}$. The low salinity plume was located far away from the coast along $18^{\circ} \mathrm{N}$ and was associated with high SST. This behaviour of the low salinity tongue can be attributed to the wind-driven coastal currents which generate an offshore Ekman transport thus pushing the southward migrating low salinity plume away from the coast [23]. The plume of low salinity waters between $86^{\circ}$ and $88^{\circ} \mathrm{E}$ along $18^{\circ} \mathrm{N}$ obviously has its origin in the rivers at the northern end of the Bay. This low salinity plume has a very shallow depth of penetration $(<10 \mathrm{~m})$ as seen in the vertical section of salinity (figure $3 b$ ). On either side of this plume, the surface salinity rapidly increased to $>32.2$; apparently the winddriven coastal upwelling and the northward currents (about $25 \mathrm{~cm} \mathrm{~s}^{-1}$ ) between $88^{\circ}$ and $90^{\circ} \mathrm{E}$ were responsible for these warm, highly saline waters. Another low salinity plume at the sea surface around $14^{\circ} \mathrm{N}$ along $90^{\circ} \mathrm{E}$ was associated with high SST. The large difference in the T-S values of the two surface low salinity plumes observed along $18^{\circ} \mathrm{N}$ and $90^{\circ} \mathrm{E}$ transects when examined with the existing flow patterns, suggests that their origins could be different. While the southward migration of runoff from the Ganges and the Brahmaputra river system appears to be driven by the southerly currents to cause a low salinity plume between $85^{\circ}$ and $87^{\circ} \mathrm{E}$, the runoff from the rivers Irrawaddy and Salween (along the Myanamar coast) coupled with warm surface waters of the northern Andaman Sea advected by a westerly current

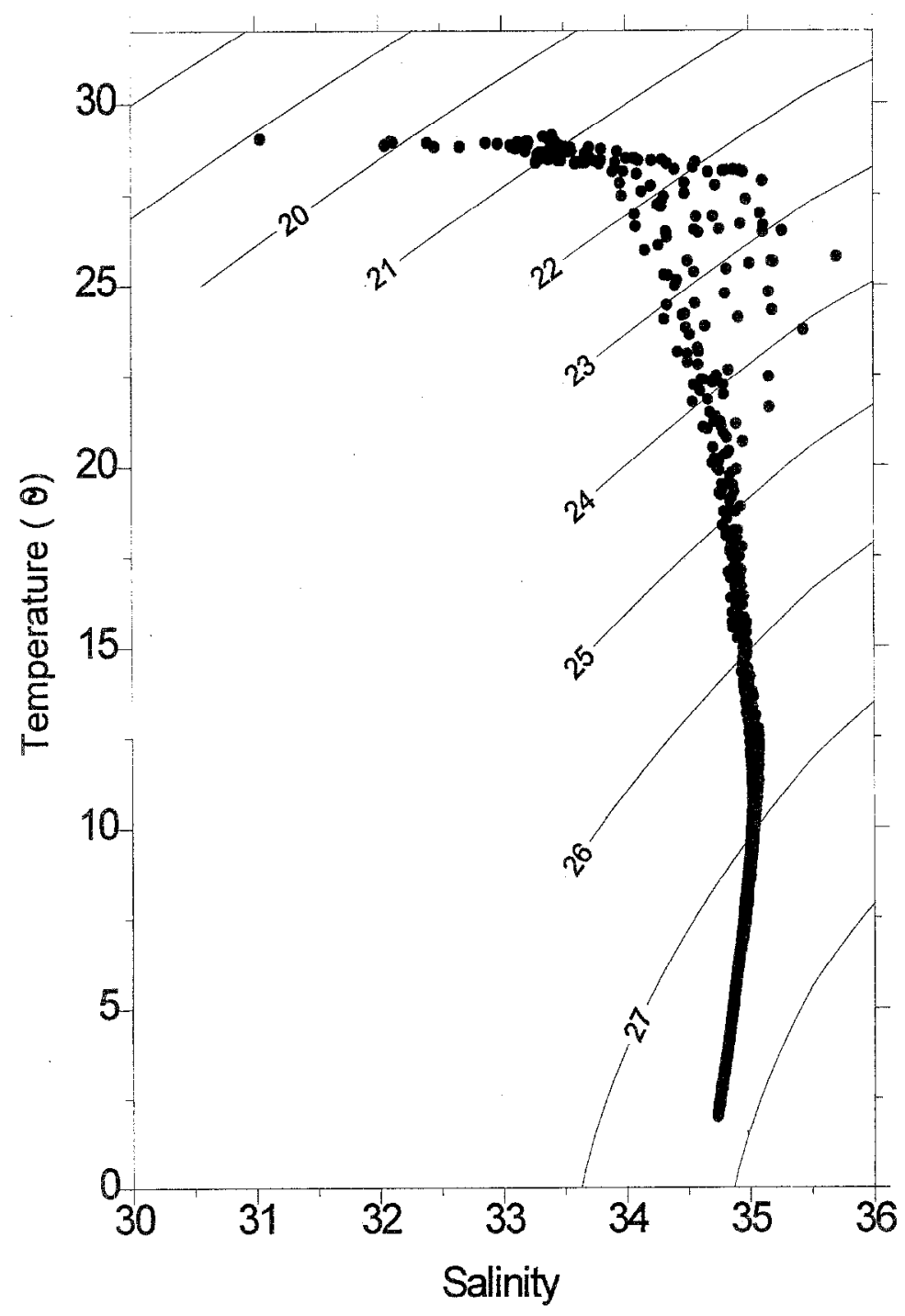

Figure 9. $\theta-\mathrm{S}$ scatter along $90^{\circ} \mathrm{E}$ transect. 
might be the source of low salinity water observed at $14^{\circ} \mathrm{N} / 90^{\circ} \mathrm{E}$. The relatively low values of $\mathrm{TCO}_{2}$ and the partial pressure of the Carbon dioxide, $\mathrm{pCO}_{2}$ (calculated from the measured $\mathrm{TCO}_{2}$ and $\mathrm{pH}$ ) along $18^{\circ} \mathrm{N}, 1560 \mu \mathrm{M}$ and $299 \mu \mathrm{atm}$ respectively, also suggest that these low salinity tongues originated from the rivers (figures $11 \mathrm{a}$ and $b$ ). Along the $90^{\circ} \mathrm{E}$ transect also the $\mathrm{TCO}_{2}$ and $\mathrm{pCO}_{2}$ were the lowest, $1878 \mu \mathrm{M}$ and $372 \mu$ atm respectively, around $12^{\circ} \mathrm{N}$. The $\mathrm{TCO}_{2}, \mathrm{pCO}_{2}$, and total alkalinity values associated with the surface high salinity water mass at $18^{\circ} \mathrm{N} / 89^{\circ} \mathrm{E}$ were $2064 \mu \mathrm{M}, 429 \mu \mathrm{atm}$ and $2391 \mu \mathrm{eq} / \mathrm{L}$ respectively while at $8^{\circ} \mathrm{N} / 90^{\circ} \mathrm{E}$ these values were found to be $1942 \mu \mathrm{M}, 411 \mu \mathrm{atm}$ and $2258 \mu \mathrm{eq} / \mathrm{L}$ respectively (figures $12 a$ and $b$ ). At the surface the total alkalinity values were also lower where the low salinity plumes were located. Its value was $1807 \mu$ eq $/ \mathrm{L}$ at $18^{\circ} \mathrm{N} / 87^{\circ} \mathrm{E}$ while it was $2200 \mu \mathrm{eq} / \mathrm{L}\left(12^{\circ} \mathrm{N} / 90^{\circ} \mathrm{E}\right)$ at a location slightly south of the low salinity tongue along $90^{\circ} \mathrm{E}$ transect (figure 13).

Along both the transects, the complex distribution of temperature and salinity generated by influx of freshwater and prevailing surface currents resulted in the observed wide scatter in the upper layer T-S structure. The two subsurface high salinity pockets along the $90^{\circ} \mathrm{E}$ transect were noticed between $6^{\circ}-8^{\circ} \mathrm{N}$ and $12^{\circ}-14^{\circ} \mathrm{N}$ in the 70 $130 \mathrm{~m}$ layer with the northern cell at a shallower depth than the southern cell. The presence of these subsurface high salinity cells in the Bay of Bengal appears to be a quasi-permanent feature linked to the monsoon circulation. Sastry et al. [19] identified them as remnants of Arabian Sea High Salinity Water mass spreading along

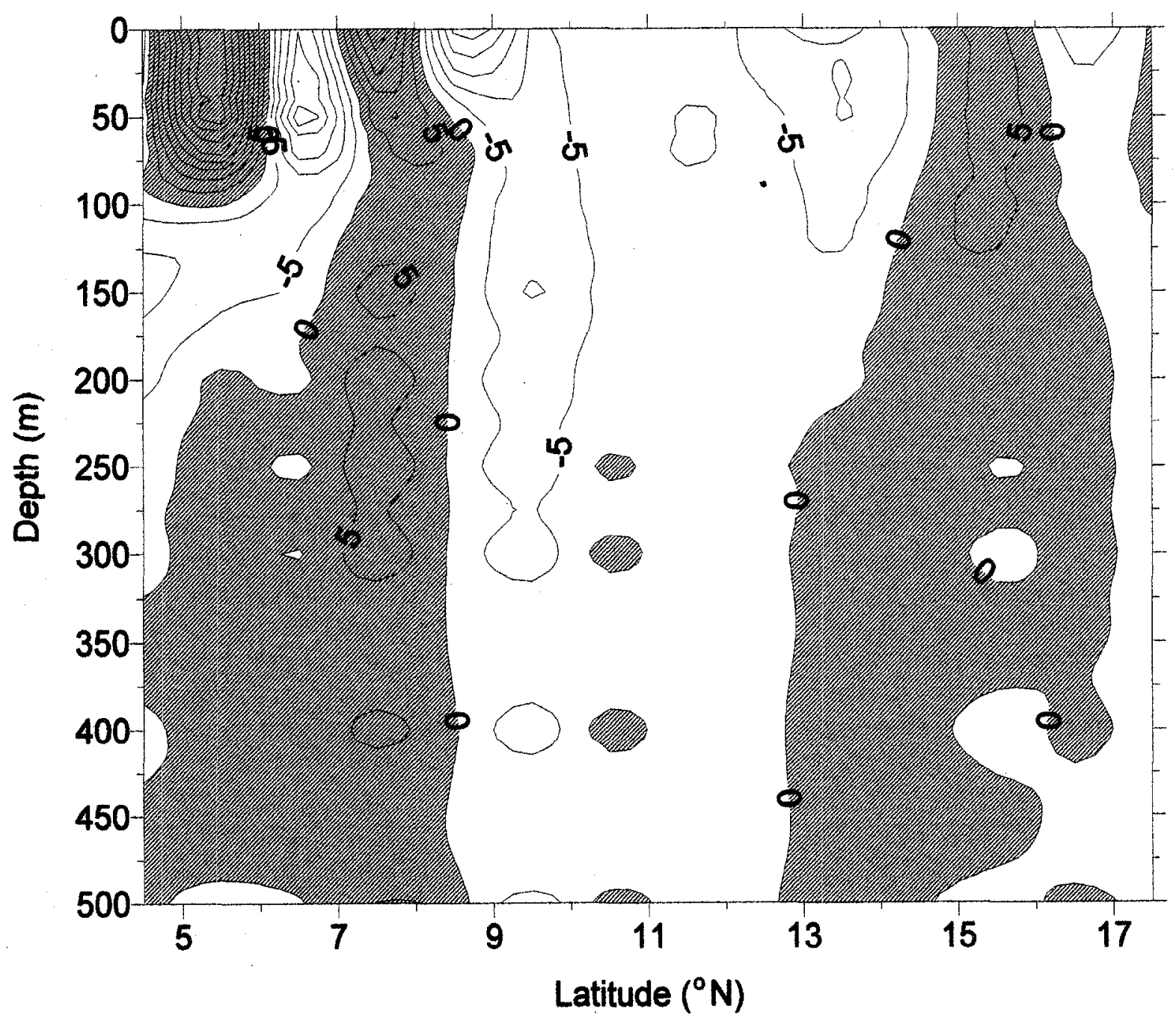

Figure 10. Vertical structure of geostrophic currents $\left(\mathrm{cm} \mathrm{s}^{-1}\right)$ across $90^{\circ} \mathrm{E}$ transect (east $\square$, west 
$400 \mathrm{cl} / \mathrm{t}$ steric (about $23.5 \sigma_{\theta}$ ) surface. Below $200 \mathrm{~m}$ depth, a nearly homogeneous layer with salinity varying around $35.05( \pm 0.05)$ was noticed to have a thickness of more than $800 \mathrm{~m}$. Earlier studies have also observed such near isohaline layer and reported it as an admixture of the Red Sea and the Persian Gulf water masses [20]. The ASHS water mass was present between 23.0 and $24.0 \sigma_{\theta}$ surfaces. At origin, it has the thermohaline indices as $\mathrm{T}=26.8^{\circ} \mathrm{C}$ and $\mathrm{S}=36.5$ occurring along $23.9 \sigma_{\theta}$ surface. During the course of its propagation, the T-S char- acteristics of the ASHS water mass undergo substantial changes and appear as small scale high salinity cells $(\mathrm{S}>35.2)$ between 23.3 and $23.8 \sigma_{\theta}$ surfaces in the southern Bay of Bengal. Though the total alkalinity value may not be a conservative property as such to use as tracer to identify the water masses, the higher alkalinity values observed around the same depths as the high salinity cells at $12^{\circ}(2357 \mu \mathrm{cq} / \mathrm{L})$ and $8^{\circ} \mathrm{N}(2308 \mu \mathrm{cq} / \mathrm{L})$ along $90^{\circ} \mathrm{E}$ transect (figure 13 ) very closely agree with typical alkalinity values of the $\Lambda$ SHS water mass.
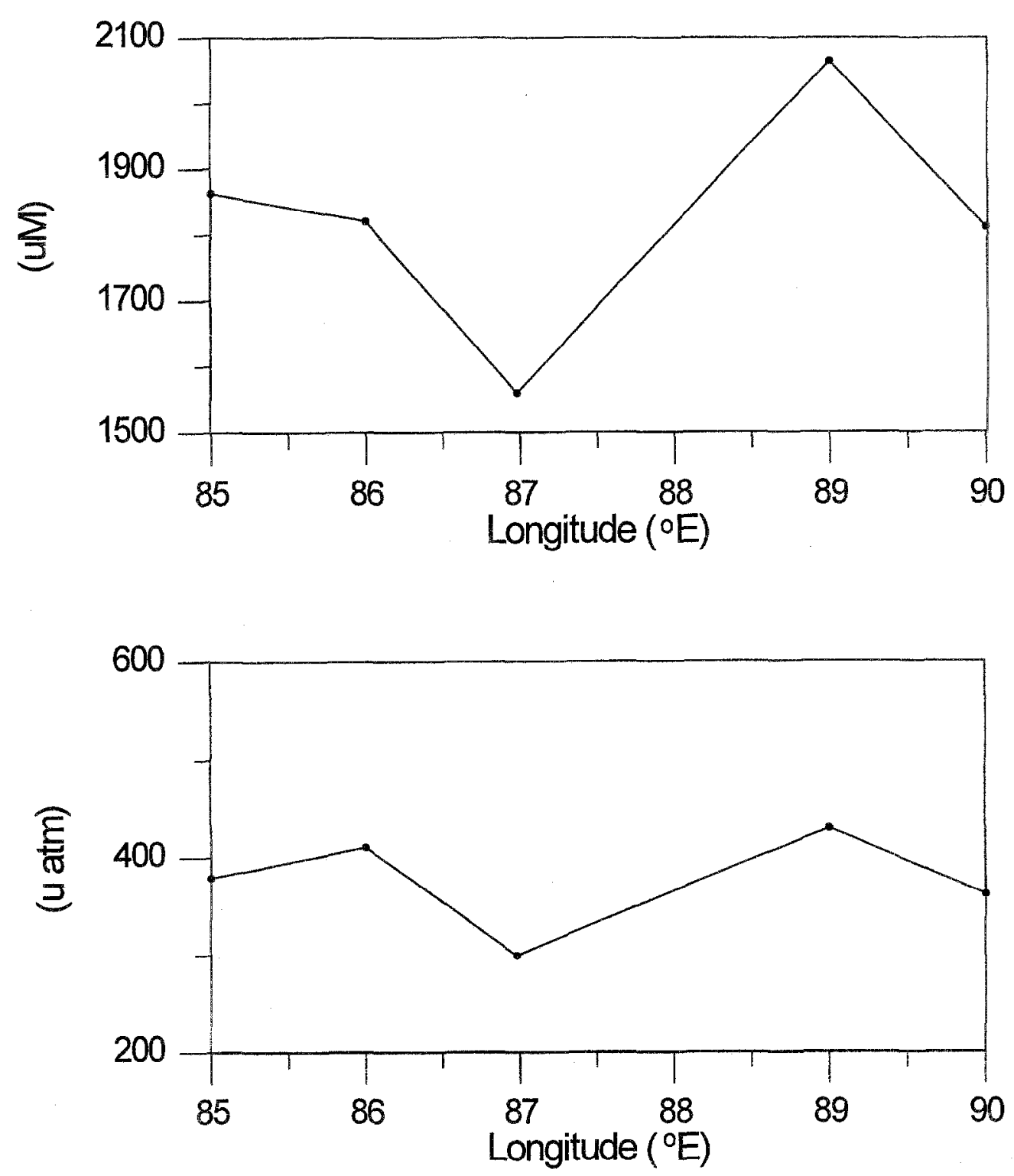

Figure 11. Distribution of surface (a) $\mathrm{TCO}_{2}(\mu \mathrm{M})$ and (b) $\mathrm{pCO}_{2}(\mu \mathrm{atm})$ along $18^{\circ} \mathrm{N}$ transect. 
The SST increased by about $0.6^{\circ} \mathrm{C}$ at $87^{\circ} \mathrm{E}$ and the surfacc salinity decreased by about 5 , a condition conducive to rise in the sea surface topography. However, the upwelling of the thermocline produced more than a compensating effect and resulted in a fall of sea surface height hy about 0.2 dyn.m. The small range of salinity variations along the $90^{\circ} \mathrm{E}$ transect had little influence on the geopotential height variations. The mixed layer depth varied from 24 to $66 \mathrm{~m}$ along $18^{\circ} \mathrm{N}$ with shallow mixed layer coinciding with warm low saline water between $87^{\circ}$ and $88^{\circ} \mathrm{E}$ where the thermocline also shoaled from about
$220 \mathrm{~m}$ at the adjacent stations to less than $180 \mathrm{~m}$ at this location. Consequently, the heat content in the upper layers decreased by $3 \times 10^{8} \mathrm{~J} \mathrm{~m}^{-2}$. On the contrary, the warm low saline water around $14^{\circ} \mathrm{N}$ deepened the thermocline depth by about $20 \mathrm{~m}$ and resulted in an increase of upper layer heat content by $2 \times 10^{8} \mathrm{~J} \mathrm{~m}^{-2}$. Along $90^{\circ} \mathrm{E}$ transect, the mixed layer depth varied between 52 and $92 \mathrm{~m}$ with deep mixed layer occurring at its southern end.

The geostrophic currents were computed relative to $1000 \mathrm{dbar}$ level, but the presentation of vertical structure
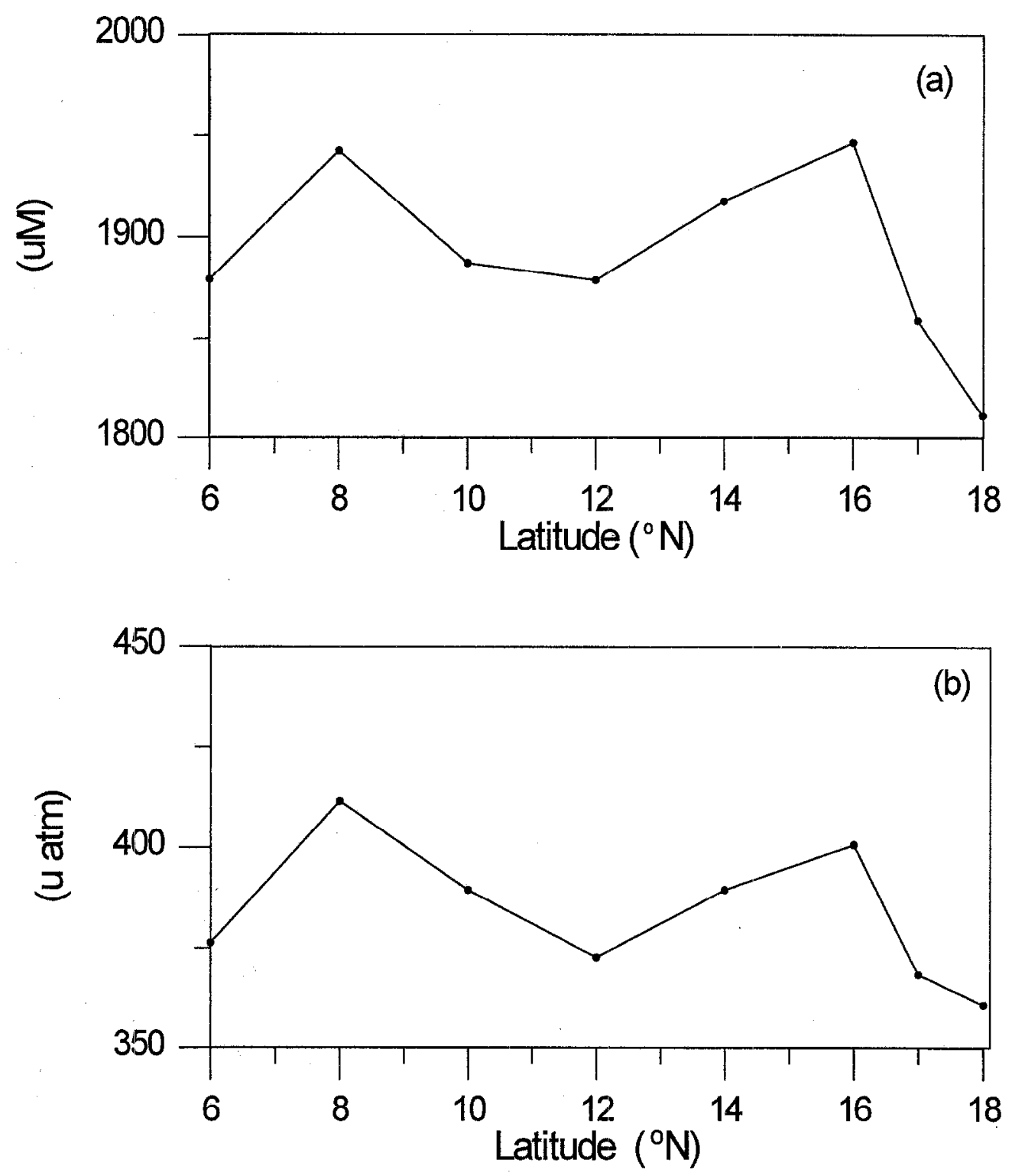

Figure 12. Distribution of surface (a) $\mathrm{TCO}_{2}(\mu \mathrm{M})$ and (b) $\mathrm{pCO}_{2}(\mu \mathrm{atm})$ along $90^{\circ} \mathrm{E}$ transect. 
of these currents was restricted to the upper $500 \mathrm{~m}$ depth only as the currents below this depth were of very small magnitude $\left(<4 \mathrm{~cm} \mathrm{~s}^{-1}\right)$. The drastic changes in the surface salinity caused by the freshwater plume at $87^{\circ} \mathrm{E}$ appear to be responsible for the formation of a density front at this location which in turn altered the sea surface slope such that it generated a southerly current towards its right and a northerly current towards it left along the $18^{\circ} \mathrm{N}$ transect. These currents were stronger in the subsurface, around $20 \mathrm{~m}$ depth $\left(>30 \mathrm{~cm} \mathrm{~s}^{-1}\right)$. Obviously the southerly currents west of $87^{\circ} \mathrm{E}$ help in driving the low salinity waters from the northern Bay while the northerly currents east of $87^{\circ} \mathrm{E}$ bring in the warm high salinity waters noticed around $89^{\circ} \mathrm{E}$ from the south. A similar trend was reported earlier by Murty et al. [15] wherein a warm transient eddy was found to cause an increase in the upper ocean heat content as far north as $20^{\circ} \mathrm{N}$.

Along the $90^{\circ} \mathrm{E}$ transect the currents showed interesting patterns such as narrow and shallow but strong easterly

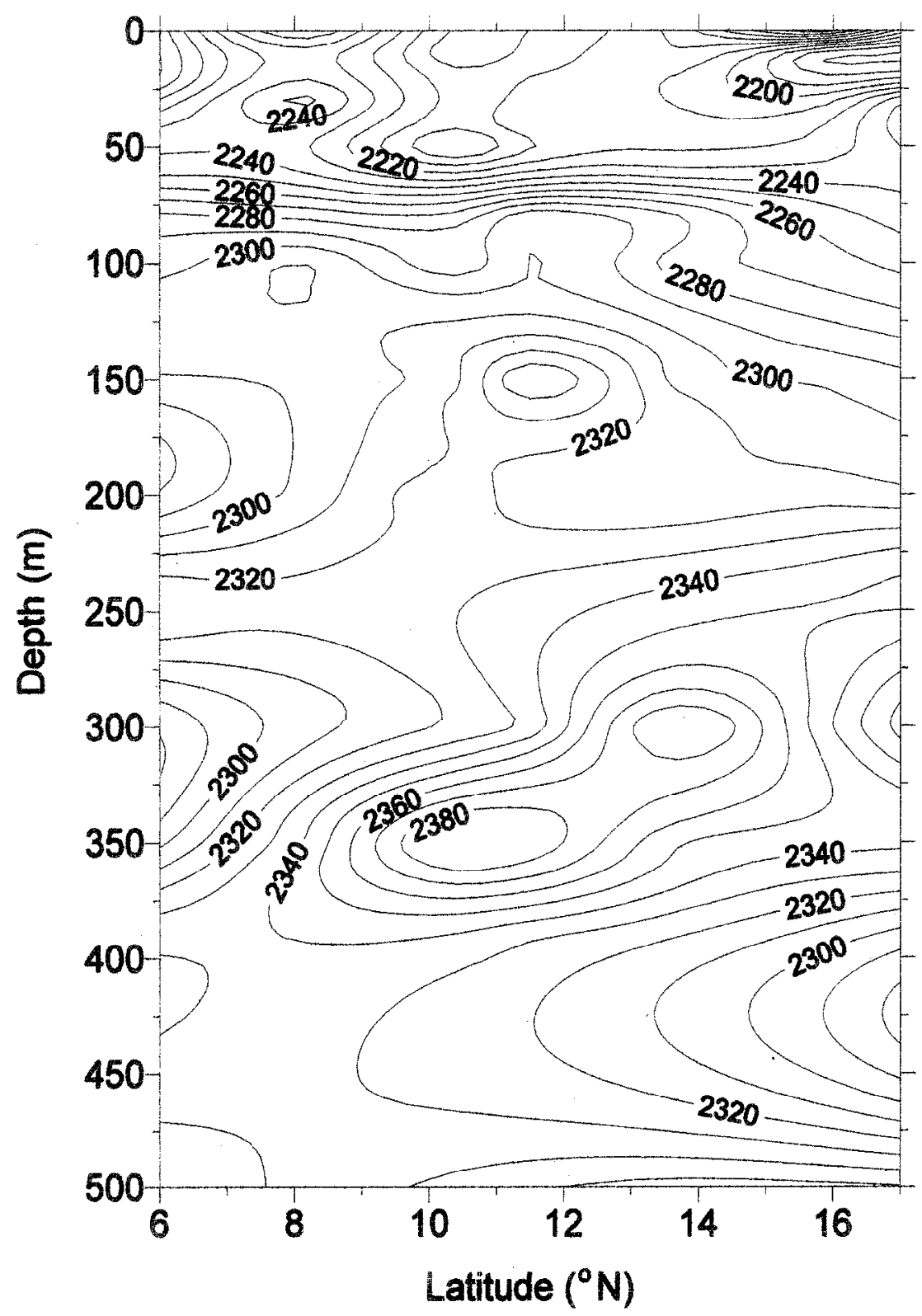

Figure 13. Distribution of total alkalinity $(\mu \mathrm{eq} / \mathrm{L})$ along $90^{\circ} \mathrm{E}$ transect. 
currents slicing a broad but weak band of westerly currents and alternate reverse flows associated with strong oscillations in geopotential height. A narrow and shallow stream of easterly current was noticed between $5^{\circ}$ and $6^{\circ} \mathrm{N}$ with a core velocity of about $45 \mathrm{~cm} \mathrm{~s}^{-1}$ around $30 \mathrm{~m}$ depth. There was another oceanographic survey conducted in June 1996, a couple of months prior to the present measurements covering the entire Bay of Bengal [14]. Figure 14 presents the pattern of the sea surface topography and associated currents during June 1996. A large anti-cyclonic gyre encompassing the entire Bay between $10^{\circ}$ and $18^{\circ} \mathrm{N}$ was present during this period. The associated flow pattern shows an easterly current north of $16^{\circ} \mathrm{N}$ and westerly currents south of this latitude. A small cyclonic gyre is also evident in this figure between $88^{\circ}$ and $91^{\circ} \mathrm{E}$ south of $12^{\circ} \mathrm{N}$. A close examina- tion of figure 14 along with figures 6 and 10 reveals that a disorganised reversal of currents had taken place as a sequel to the local wind and freshwater forcing imparted to the surface layers of the Bay of Bengal during the southwest monsoon season, particularly in the northern regions of the Bay.

The surface circulation was further examined using trajectories of the drifting buoys available during JuneDecember, 1996 in this region. Figure 15, showing drifting buoy trajectories, was prepared using GMT software [27]. The drifting buoy (ID:11356) deployed at $16^{\circ} \mathrm{N} / 90^{\circ} \mathrm{E}$ on 5 September, 1996 in the eastern Bay initially moved southwards until the end of September and then made an about turn towards the north around the beginning of October. We hypothesise that this deflection of the surface current was due the arrival of IMC at

\section{Longitude $\left({ }^{\circ} \mathrm{E}\right)$}

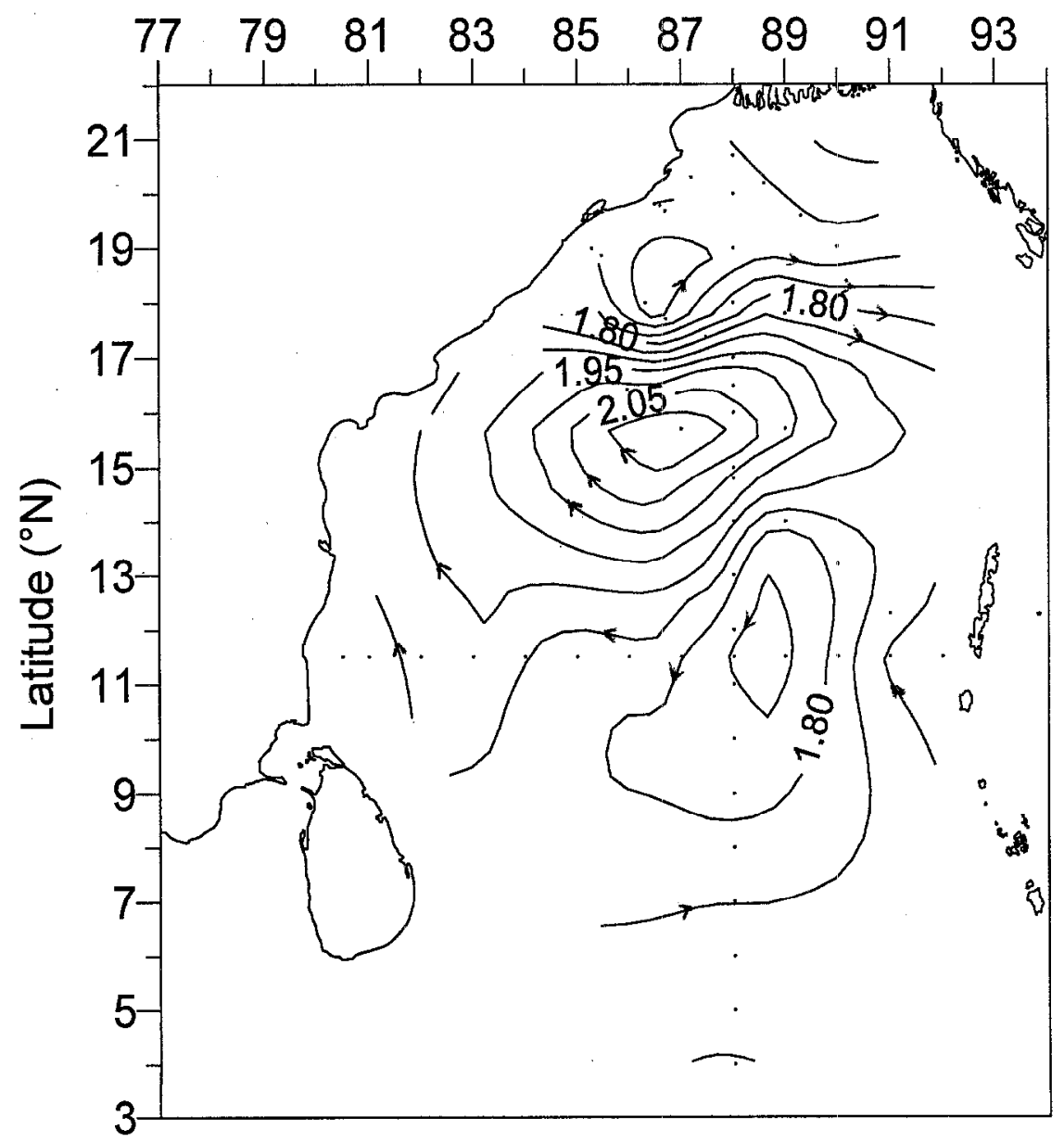

Figure 14. Sea surface topography (dyn.m) during June 1996. 
around $12^{\circ} \mathrm{N}$ along the eastern rim of the Bay (figure $15 a$ ). The trajectory of another drifting buoy (ID:11353) deployed at $11.5^{\circ} \mathrm{N} / 84^{\circ} \mathrm{E}$ on 7 June, 1996 shows the presence of an eddy along the southeast coast of India (figure 15b). It initially moved westwards and then slug-

Trajectory of 11356

$$
\text { (05.09-96 to 30-12-36) }
$$
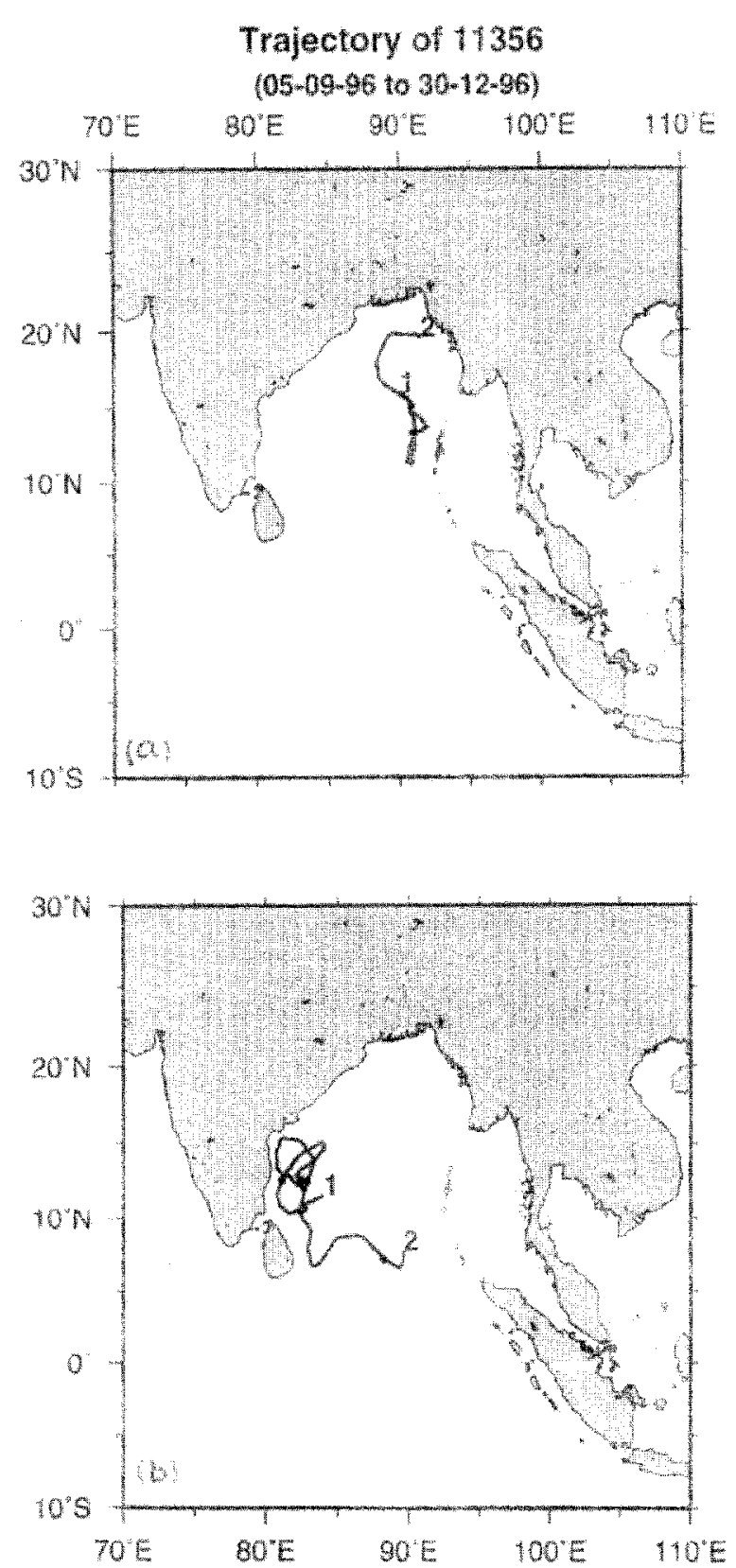

Trajectory of 11353

$(07-06-96$ to $07-10.96)$ gishly moved along the coast towards the north and drifted into an anticyclonic eddy before eventually moving towards the south by the end of August. The drifter then entrained into the eastward propagating IMC along the southern boundary of the Bay of Bengal. The flow

\section{Trajectory of 11357 \\ (10-09-96 to 04-11.96)}

$70^{\circ} \mathrm{E} \quad 80^{\circ} \mathrm{E} \quad 90^{\circ} \mathrm{E} \quad 100^{\circ} \mathrm{E}$ THE
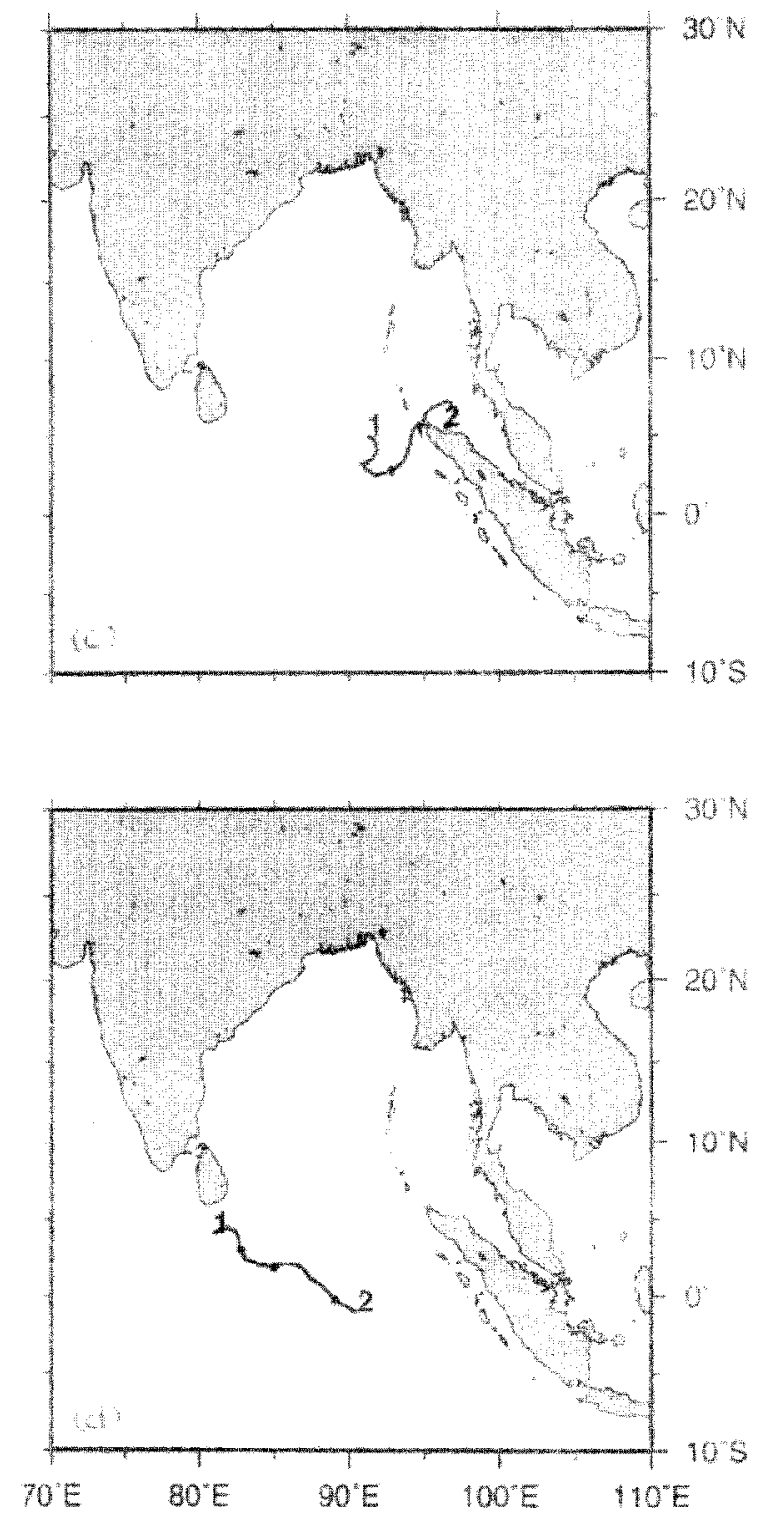

Trajectory of 11354

(30-08-96 to 09-12-96)

Figure 15. Trajectories of the drifting buoys during June-December, 1996 in the Bay of Bengal. Dot (.) indicates beginning of a month within the period mentioned. 1 and 2 represent the beginning and end of the above-mentioned periods. 
pattern shown in figure 14 also confirms the existence of a northward coastal current along the east coast of India. But near the equatorial region, the trajectories of the drifting buoys (ID: 11357 and 11354) show that the surface currents were largely towards the east (figures $15 \mathrm{c}$ and $d$ ). These drifting buoys appeared to be following different branches of the monsoon drift current near the equatorial region which had set in by the time these buoys were deployed. It may be seen that while the geostrophic compulations showed a northerly current around $18^{\circ} \mathrm{N} /$ $90^{\circ} \mathrm{E}$, the drifting buoy trajectory pointed to a southward flow during September. This could mean that the signatures of a shallow southward flow in this region are smeared out due to the effects inherent in geostrophic method which cumulates the dynamic height from a deep reference level to yield the geostrophic currents. This
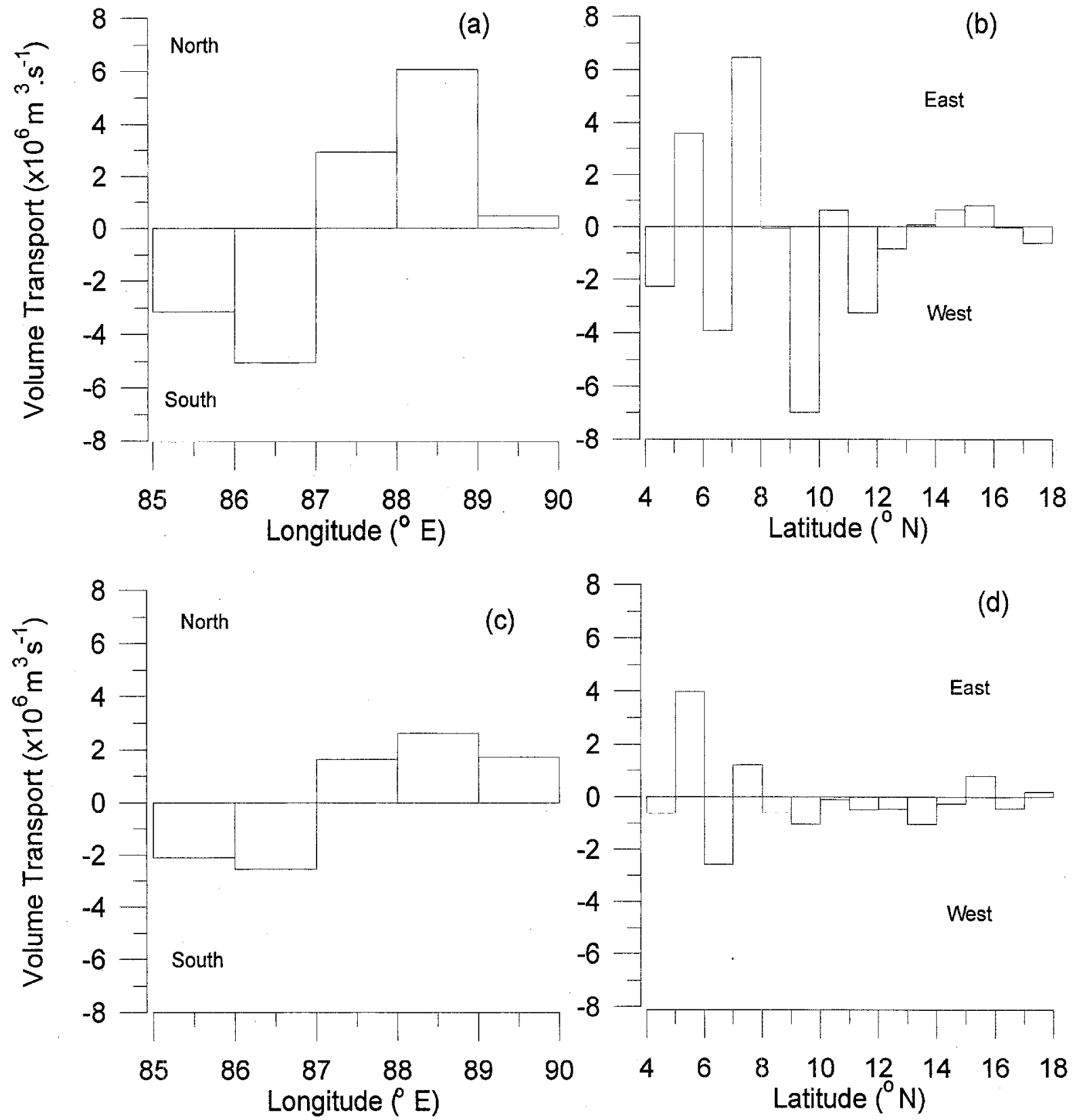

Figure 16. Vertical structure of volume transport $\left(10^{6} \mathrm{~m}^{3} \mathrm{~s}^{-1}\right)$ in the (a, b) 0-1000 m. Along the $18^{\circ} \mathrm{N}$ and $90^{\circ}$ transects respectively, (c, d) $0-100 \mathrm{~m}$ layers along $18^{\circ} \mathrm{N}$ and along $90^{\circ} \mathrm{E}$ transects respectively. 
result leads us to state that the geostrophic method misrepresents the surface currents in the northern Bay of Bengal where a large volume of freshwater influx occurs during the southwest monsoon period. The northward current in this region may well remain as a subsurface current. The higher core velocities across this section (figure 6) support this inference. The drifters 11353 , 11354 , and 11357 indicated the pathways of warm saline waters from the equatorial region that were observed along the $90^{\circ} \mathrm{E}$ transect. The pattern of the surface currents derived from the ship drifts [7] also supports the circulation features derived from this study. The geostrophic computations showed a relatively strong surface current $\left(>25 \mathrm{~cm} \mathrm{~s}^{-1}\right.$ ) penetrating up to about $150 \mathrm{~m}$ depth in the southern region of the $90^{\circ} \mathrm{E}$ transect but very rapidly weakened to about $5 \mathrm{~cm} \mathrm{~s}^{-1}$ and shoaled to $<5 \mathrm{~m}$ depth as they moved northwards. The flow pattern was dominated by westward currents over a large part of the transect between $8^{\circ}$ and $15^{\circ} \mathrm{N}$ (figure 10). Strong oscillations as depicted by alternating currents between $4^{\circ}$ and $9^{\circ} \mathrm{N}$ across $90^{\circ}$ E transect could possibly be caused by the westward-propagating low frequency waves such as Rossby waves [12], solitons [2] which are known to bc present in the southeastern Bay of Bengal or the mesoscale gyres generated by complex bathymetry of $90^{\circ} \mathrm{E}$ ridge and the poleward propagating IMC along the eastern rim of the Bay. At $8^{\circ} \mathrm{N}$ the surface high salinity waters associated with low SST appeared to have been derived from the equatorial region through an easterly current $\left(25 \mathrm{~cm} \mathrm{~s}^{-1}\right)$ between $7^{\circ}$ and $8^{\circ} \mathrm{N}$.

The volume transport was estimated from the geostrophic velocity field relative to the $1000 \mathrm{dbar}$ level. Across the $18^{\circ} \mathrm{N}$ transect, the volume transported was found to be of the order of $8 \times 10^{6} \mathrm{~m}^{3} \mathrm{~s}^{-1}$ towards the south and $9.5 \times 10^{6} \mathrm{~m}^{3} \mathrm{~s}^{-1}$ towards the north, resulting in a net northward volume transport of $1.5 \times 10^{6} \mathrm{~m}^{3} \mathrm{~s}^{-1}$ in the upper $1000 \mathrm{~m}$ (figure 16a). Reversal of currents and associated volume transport in the subsurface was also noticed along this transect. The June 1996 hydrographic data showed a net poleward transport of about
$11 \times 10^{6} \mathrm{~m}^{3} \mathrm{~s}^{-1}$ along the western boundary of the Bay of Bengal [14]. Thus the reversal of circulation driven by southwest monsoon winds and freshwater appears to have resulted in a significant reduction in northward volume transport in the Bay of Bengal. In the upper $1000 \mathrm{~m}$ across the $90^{\circ} \mathrm{E}$ transect, the flow pattern was dominated by westward currents in the northern regions and by alter. nating flows between $4^{\circ}$ and $10^{\circ} \mathrm{N}$. Consequently, the volume transport was found to be about $18 \times 10^{6} \mathrm{~m}^{3} \mathrm{~s}^{-1}$ towards the west and $12 \times 10^{6} \mathrm{~m}^{3} \mathrm{~s}^{-1}$ towards the east resulting in a net westward volume transport across the $90^{\circ} \mathrm{E}$ transect of $6 \times 10^{6} \mathrm{~m}^{3} \mathrm{~s}^{-1}$ (figure $16 \mathrm{~b}$ ). Reversals in the subsurface currents resulted in identical changes in volume transport at a few stations along these two transects. Integrated volume transport was also vertically divided into mutually opposite directions where strong opposing currents were present. The volume transports in the upper layer $(0-100 \mathrm{~m})$ were found to be about $4.5 \times 10^{6} \mathrm{~m}^{3} \mathrm{~s}^{-1}$ and $6 \times 10^{6} \mathrm{~m}^{3} \mathrm{~s}^{-1}$ towards the south and north respectively across the $18^{\circ} \mathrm{N}$ transect (figure $16 \mathrm{c}$ ). While they were $6.5 \times 10^{6} \mathrm{~m}^{3} \mathrm{~s}^{-1}$ and $8 \times 10^{6} \mathrm{~m}^{3} \mathrm{~s}^{-1}$ towards the east and west respectively across the $90^{\circ} \mathrm{E}$ transect (figure $16 d$ ). It shows that 50 to $70 \%$ of the volume transport in the Bay of Bengal occurs in the upper $100 \mathrm{~m}$. Thus the dynamics of the bottom layer may be relatively insignificant.

\section{Acknowledgement}

The authors express their gratitude to Shri. L.V.G. Rao, Head, Physical Oceanography Division and Dr. Ehrlich Desa, Director, National Institute of Oceanography, Goa for their support, and to the Department of Ocean Development (DOD), New Delhi for the data acquisition facilities onboard ORV Sagar Kanya. Two of the authors (EPR and VVSSS) wish to thank DOD, New Delhi for the research fellowships. This study is supported under institute's R\&D project ILP040129. Figures 1 and 14 were prepared using GMT software. The authors are thankful to the reviewer for helpful suggestions.

\section{REFERENCES}

[1] Anonymous, Admiralty Manual of Hydrographic Surveying, Vol. 1, Hydrographer of Navy, London, Butler and Tanner Ltd., London (1965) 20-26.

[2] Apel J.R., Thompson D.R., Tilley D.G., van Dyke P., Hydrodynamics and Radar Signatures of Internal Solitons in the
Andaman Sca, The Johns Hopkins APL Tech. Digest 6 (1985) 330-337.

[3] Babu M.T., Prasannakumar S., Rao D.P., A Subsurface Cyclonic Eddy in the Bay of Bengal. J. Mar. Res. 49 (1991) 403-411. 
[4] Babu M.T., Sarma Y.V.B., Murty V.S.N., Vethamony P., Western Boundary Current and associated eddies in the Bay of Bengal, J. Geophys. Res. (submitted).

[5] Balaramamurty C., Ramasastry A.A., Distribution of Density and the Associated Currents at the Sea Surface in the Bay of Bengal, Ind. J. Meteor. Geophys. 8 (1957) 88-92.

[6] Colborn J.G., The Thermal Structure of Indian Ocean, The University Press of Hawaii, Honolulu, 1975.

[7] Cutler A.N., Swallow J.C., Surface Currents of the Indian Ocean (to $25^{\circ} \mathrm{S}, 100^{\circ} \mathrm{E}$ ): compiled from historical data archived by the Meteorological Office, Bracknell, UK, IOS Report No. 187, 8 p. 36 charts, 1984.

[8] Düing W., The Monsoon Regime of the Currents in the Indian Ocean, IIOE Monographs No. 1, East-West Press, Hawaii, USA, 1970.

[9] Emery W.J., The Role of Vertical Motions in the Heat Budget of the Upper Ocean, PhD. dissertation, Hawaii Inst., Geophysics, Univ. Hawaii, USA, 1975, 81 p.

[10] George M.D., Kumar M.D., Naqvi S.W.A., Banerjee S., Narvekar P.V., de Souza S.N., Jayakumar D.A., A study of Carbon Dioxide System in the Northern Indian Ocean During Premonsoon, Mar. Chem. 47 (1994) 243-254.

[11] Hanson D.V, Poulain P.M., Processing of WOCE/TOGA drifter data, J. Atmos. Oceanic Techonol. 13 (1996) 900-909

[12] McCrcary J., Kundu P., Molinari R.L., A Numcrical Investigation of Dynamics, Thermodynamics and Mixed Layer Processes in the Indian Ocean. Progr. Oceanogr. 31 (1993) 181-244.

[13] Molinari R.L., Olson D., Reverdin G., Surface Current Distributions in the Tropical Indian Ocean Derived from Compilation of Surface Buoy Trajectories, J. Geophys. Res. 95 (1990) $7217-7238$.

[14] Murty V.S.N., Gupta G.V.M., Sarma V.V., Rao B.P., Jyothi D., Sastry P.M.N., Supraveena Y., Effect of Vertical Stability and Circulation on the Depth of Chlorophyll Maxima in the Bay of Bengal during May-June, 1996, Deep Sea Res. (submitted).

[15] Murty V.S.N., Sarma Y.V.B., Rao D.P., Variability of the Oceanic Boundary Layer Characteristics in the Northern Bay of Bengal during MONTBLEX-90, Proc. Indian Acad. Sci. (Earth and Planet. Sci.), 105 (1996) 41-61.

[16] Murty V.S.N., Sarma Y.V.B., Babu M.T., Rao D.P., Hydrography and Circulation in the Northwestern Bay of Bengal during the Retreat of Southwest Monsoon, Proc. of Indian Acad. Sci. (Earth and Planet. Sci.), 101 (1992a) 67-75.

[17] Murty V.S.N., Sarma Y.V.B., Rao D.P., Murty C.S., Water Characteristics, Mixing and Circulation in the Bay of Bengal during Southwest Monsoon, J. Mar. Res. 50 (1992b) 207-228.

[181 Sarma Y.V.B., Murty V.S.N., Rao D.P., Distribution of Cyclone Heat Potential in the Bay of Bengal, Indian J. Mar. Sci. 19 (1990) 102-106.

[19] Sastry J.S., Rao D.P., Murty V.S.N., Sarma Y.V.B., Suryanarayana A., Babu M.T., Water mass Structure in the Bay of Bengal, Mahasagar 18 (1985) 153-162.

[20] Sastry J.S., Premchand K., Murty C.S., Water mass Structure in the Western Indian Ocean, Part I: Water masses and their Thermohaline Indices, Mausam 37 (1986) 107-110.

[21] Shcherbinin A.D., Geostrophic Water Circulation in the Indian Ocean, Oceanology 9 (1973) 649-654.

[22] Shenoi S.C., Saji P.K., Almeida A.M., Rama Rao E.P., Michael G.S., Nampoothiri G., Gangadhara Rao L.V., Drifter Observations in the Indian Ocean (August 1993-April 1997), Data Report, National Institute of Oceanography, India, 1997.

[23] Shetye S.R., The Movement and Implications of the GangesBramhaputra Runoff on Entering the Bay of Bengal, Current Sci. 64 (1993) 32-38.

[24] Suryanarayana A., Murty V.S.N., Sarma Y.V.B., Babu M.T., Rao D.P., Sastry J.S., Hydrographic Features in the upper $500 \mathrm{~m}$ of the western Bay of Bengal under the Influence of NE and SW Monsoons, in: Desai B.N. (Ed.), Oceanography of the Indian Ocean, Oxford and IBH Publishing Co., New Delhi, 1992, p. 595-604.

[25] Varkey M.J., Salt Balance and Mixing in the Bay of Bengal, Ph.D thesis, Univ. Kerala, India, 1986.

[26] Varkey M.J., Murty V.S.N., Suryanarayana A., Physical Oceanography of the Bay of Bengal and Andaman Sea, Oceanogr. Mar. Biol.: an Annual Review, 34 (1996) 1-70.

[27] Wessel P., Smith W.H.F., Free software help map and display data, EOS, Amer. Geophys. Union 72 (1991) 441, 445-446.

[28] Wyrtki K., Oceanographic Atlas of the Intermational Indian Ocean Expedition. National Science Foundation, Washington DC, USA, 531 charts, 1971. 